\title{
Fruit Juice Production Using Ultraviolet Pasteurization: A Review
}

\author{
Nor Nadiah Abdul Karim Shah ${ }^{1}$, Rosnah Shamsudin ${ }^{1}$, Russly Abdul Rahman ${ }^{2}$ \\ and Noranizan Mohd Adzahan 2,* \\ 1 Department of Process \& Food Engineering, Faculty of Engineering, Universiti Putra Malaysia, \\ 43400 Serdang, Selangor Darul Ehsan, Malaysia; nadiahkarim@upm.edu.my (N.N.A.K.S.); \\ rosnahs@upm.edu.my (R.S.) \\ 2 Department of Food Technology, Faculty of Food Science and Technology, Universiti Putra Malaysia, \\ 43400 Serdang, Selangor Darul Ehsan, Malaysia; russly@upm.edu.my \\ * Correspondence: noraadzahan@upm.edu.my; Tel.: +603-8946-8392
}

Academic Editor: Tatiana Koutchma

Received: 29 March 2016; Accepted: 1 August 2016; Published: 5 August 2016

\begin{abstract}
Ultraviolet (UV-C at $253.7 \mathrm{~nm}$ ) technology has been the go-to alternative pasteurization and shelf-life extension treatment for beverages for the last two decades. It has been the focal point of non-thermal methods for fruit juice processing and has been studied extensively. UV-C technology has been proven to produce microbiologically safe products with minimal negative impact towards quality of the products. However, due to the physicochemical characteristics of fruit juice, application of UV-C does have certain limitations and thus, there is a need to further study the effects of UV-C-treatment and equipment design. Critical decisions on the type of fruit product, juice color, juice composition, and juice physical characteristics, among other variables, are imperative to produce a safe and wholesome juice. Therefore, this paper serves as a source for development of UV-C technology for pasteurization and shelf-life extension of fruit juice to successfully obtain a final product with minimal changes of its nutritional component without neglecting the microbial safety. It reviews previous literatures involving ultraviolet-treated fruit juices, ranging from popular apple and orange juice to lesser-known pummelo and pitaya juice. The review also covers the aspect of microbiological and chemical safety, quality, and sensory characteristics as well as hurdle technology involving UV-C as the main method and the market potential with its cost implication of UV-C technology.
\end{abstract}

Keywords: ultraviolet irradiation; fruit juice; pasteurization; quality; beverages

\section{Introduction}

Food processing and preservation techniques are continuously being developed to conform to modern consumer demands for safe and healthier foods. Higher income, urbanization, demographic shifts, improved transportation, and consumer perceptions regarding quality and safety are changing global food consumption [1]. Modern consumers demand tasty, healthier, natural and fresh-like foods, produced in an environmentally friendly manner with sustainable methods and small carbon footprints [2-4]. As a consequence, in the past two decades non-thermal technologies have received increasing attention due to its potential for inactivating spoilage and pathogenic microorganisms [5]. Ultraviolet (UV-C) light system is a non-thermal technology which has acquired interests among food researchers. Numerous studies have proven that the germicidal UV-C light treatment holds considerable promises in juice processing as an alternative to traditional thermal treatment. When compared with traditional thermal pasteurization method for liquid foods such as High Temperature-Short Time (HTST), UV-C treatment was shown to have had a minimal effect on the 
quality of juice. However, effects of UV-C towards the physicochemical characteristics and nutritional composition of UV-C treated juice cannot be overlooked. Depending on the UV processing dose and specific nutrient(s), UV light may have varying effect on nutrient and enzyme retention as the success of UV technology depends on the correct alignment of the UV source and system parameters to the specific demands of the UV juice application $[2,6]$.

UV-C light is the short electromagnetic spectrum between 200 to $280 \mathrm{~nm}$. With its positive consumer image and low processing cost, UV-C treatment is proven to be suitable for fruit juice stabilization [3]. Its bactericidal mechanism is based on the absorption of UV-C light by microbial DNA or RNA structures. The primary mechanism is the creation of pyrimidine dimers, which prevent microorganisms from replicating, further rendering them inactive and unable to cause infection [7]. The use of UV-C light for water treatment is well established, however, the application of UV-C on liquid foods presents a relatively new challenge to beverage producers. Compared to water, liquid foods have a range of optical and physical properties and diverse chemical compositions that influence UV-C light transmittance, dose delivery, momentum transfer and-consequently-microbial inactivation. The United States Food and Drug Administration (USFDA) and United States Department of Agriculture (USDA) [8], have concluded that the usage of UV-C light at $253.7 \mathrm{~nm}$ for food processing is safe and has further approved the usage as an alternative treatment to reduce pathogens and other microorganisms. USFDA issued Code 21CFR179.41, which approved the use of UV-C light in the production, processing, and handling of food. Critical factors to ensure efficient UV-C treatment include; transmissivity of the product, geometric configurations of the reactor, power, wavelength and physical arrangement of the UV-C sources, product profile and radiation path length $[2,4]$.

This paper provides a general review of the UV-C light applications and its effect on the quality and shelf-life extensions, sensory effects of UV-C-irradiated juice, and the hurdle pasteurization technology involving UV-C-irradiation. The market potential and cost implications were also discussed.

\section{Quality and Shelf Life Extension of UV-C-Irradiated Juices}

The use of non-thermal processing technology such as ultraviolet irradiation is motivated by the fact that fruit juices contain nutrients and other compounds which are heat sensitive. Various studies have highlighted the benefits of using ultraviolet irradiation with regard to nutrient retention and storage stability and in the past twenty years the usage of UV-C light are well documented with samples ranging from citrus juice to tropical juices. This is reflected in Table 1 where the effects of UV-C-irradiation on treated fruit juices is also highlighted. As a consequence, crucial precaution in terms of dosage and exposure applied to the fruit juice should be monitored.

Table 1. Effects of UV-C-irradiation on quality improvement and shelf life extension of fruit juices.

\begin{tabular}{|c|c|c|c|}
\hline Medium & Variables & Effects & References \\
\hline \multirow{3}{*}{ Orange juice } & $\mathrm{UV}-\mathrm{C}$ dose $=299 \mathrm{~mJ} / \mathrm{cm}^{2}$ & $17 \%$ reduction of ascorbic acid after 7 passes. & {$[2]$} \\
\hline & $\begin{array}{l}\text { UV-C dose }=12.3-148 \\
\mathrm{~mJ} / \mathrm{cm}^{2}\end{array}$ & $\begin{array}{l}5 \% \text { reduction of PME activity and } \mathrm{pH} \text { change } 17 \% \text { losses of } \\
\text { ascorbic acid. }\end{array}$ & [9] \\
\hline & UV-C dose $=12-48 \mathrm{~kJ} / \mathrm{L}$ & $\begin{array}{l}\text { Ascorbic acid losses increased in line with the UV-C doses, } \\
\text { significant after } 48 \mathrm{~kJ} / \mathrm{L} \text { of UV-C dose. } \\
\text { No significant reduction total phenols and antioxidant capacity. } \\
\text { No significant changes towards pH, total soluble solids content and } \\
\text { titration acidity. }\end{array}$ & [10] \\
\hline Mango nectar & UV-C dose $=45 \mathrm{~J} / \mathrm{cm}^{2}$ & Reduction of polyphenol oxidase activity to $25 \%$. & [4] \\
\hline
\end{tabular}


Table 1. Cont.

\begin{tabular}{|c|c|c|c|}
\hline Medium & Variables & Effects & References \\
\hline \multirow{5}{*}{ Apple juice } & $\begin{array}{l}\text { UV-C dose = } \\
2.66-53.1 \mathrm{~J} / \mathrm{cm}^{2}\end{array}$ & $\begin{array}{l}\text { Significant decrease in total phenol content, while antioxidant } \\
\text { capacity was not reduced significantly. } \\
\text { No significant changes in } \mathrm{pH} \text {, soluble solids content and } \\
\text { titration acidity. }\end{array}$ & [5] \\
\hline & $\begin{array}{l}\text { UV-C dose = } \\
10 \mathrm{~mW} / \mathrm{cm}^{2}\end{array}$ & $\begin{array}{l}\text { UV-C induced minimal of furan at dose less than } 3.5 \mathrm{~J} / \mathrm{cm}^{2} \text {. } \\
\text { At } 8.8 \mathrm{~J} / \mathrm{cm}^{2}, \sim 14 \mathrm{ppb} \text { furan was formed. Furan formation was } \\
\text { increased at a rate of } 11 \mathrm{ppb} \text { per } \mathrm{J} / \mathrm{cm}^{2} \text {. }\end{array}$ & [11] \\
\hline & UV-C (NA) & $\begin{array}{l}\text { No significant changes in } \mathrm{pH} \text {, soluble solids content, and titration } \\
\text { acidity. Reduction of vitamin C is highly dependent on } \\
\text { juice varieties. } \\
\text { Golden's vitamin C reduction }=5.7 \% \text {, Starking's }=5.6 \% \text {, Fuji's }=4 \% \text {, } \\
\text { King David's }=70 \% \text {. The losses can be attributed to the lack of } \\
\text { pigmentation of juice. } \\
\text { No PME activity was found after UV-C treatment and it completely } \\
\text { inactivate PPO and peroxidase after } 100 \text { and } 15 \text { min, respectively. }\end{array}$ & [12] \\
\hline & $\begin{array}{l}\text { UV-C dose }=2.66,5.31 \\
10.62,26.55 \text { and } \\
53.1 \mathrm{~mJ} / \mathrm{cm}^{2}\end{array}$ & $\begin{array}{l}\text { No significant changes in } \mathrm{pH} \text {, soluble solids content, total phenol } \\
\text { content, and titratable acidity. While color attributes showed } \\
\text { significant effect with direct impact towards non-enzymatic } \\
\text { browning index and TEAC decreased as UV-C doses increased. }\end{array}$ & [13] \\
\hline & $\begin{array}{c}\text { UV-C dose = } \\
39-245 \mathrm{~mJ} / \mathrm{cm}^{2}\end{array}$ & $\begin{array}{l}\text { The study did not have a noticeable effect on enzyme activities of } \\
\text { naturally cloudy apple juice }\left(\alpha=61 \mathrm{~cm}^{-1}\right) \\
\text { Furan was seen to increase from } 2.3 \text { to } 3.7 \mu \mathrm{g} / \mathrm{kg} \text {. }\end{array}$ & [14] \\
\hline \multirow{4}{*}{ Apple cider } & $\begin{array}{l}\text { UV-C dose }=4.45,6.67 \\
\text { and } 13.34 \mathrm{~mJ} / \mathrm{cm}^{2}\end{array}$ & $\begin{array}{l}\text { Significant effects were detected on viscosity, turbidity, } \\
\text { PPO residual activity. }\end{array}$ & [15] \\
\hline & $\mathrm{UV}-\mathrm{C}$ dose $=14 \mathrm{~mJ} / \mathrm{cm}^{2}$ & $\begin{array}{l}\text { Titratable acidity was found to increase, whereas turbidity } \\
\text { decreased. No significant difference was found on soluble solids } \\
\text { content and } \mathrm{pH} \text {. }\end{array}$ & [16] \\
\hline & UV-C (NA) & $\begin{array}{l}\text { No significant effect was found on } \mathrm{pH} \text {, sedimentation, and glucose } \\
\text { and fructose. } \\
\text { Whereas, significant decrease was detected on turbidity, soluble } \\
\text { solids content and significant increment was shown on total } \\
\text { color changes. }\end{array}$ & [17] \\
\hline & $\begin{array}{l}\text { UV-C dose = } \\
8.77-35.11 \mathrm{~mJ} / \mathrm{cm}^{2}\end{array}$ & $\begin{array}{l}\text { Significant decrease on color } L^{*} \text { values, turbidity, and viscosity, } \\
\text { whereas } \mathrm{pH} \text { seemed to increase. } \\
\text { Storage studies: Color } L^{*} \text { increased, no significant changes toward } \\
\text { turbidity and } \mathrm{pH} \text {, whereas viscosity seemed to increase. }\end{array}$ & [18] \\
\hline $\begin{array}{l}\text { Apple and } \\
\text { grape juice }\end{array}$ & UV-C dose $=4.02 \mathrm{~kJ} / \mathrm{L}$ & $\begin{array}{l}\text { A decrease in color } L^{*} \text { value and viscosity was detected in } \\
\text { both juice. }\end{array}$ & [19] \\
\hline Grape juice & $\begin{array}{l}\text { UV-C dose }= \\
40-300 \mathrm{~mJ} / \mathrm{cm}^{2}\end{array}$ & $\begin{array}{l}\text { Turbidity of pasteurized clear grape juice (PCGJ) was observed to } \\
\text { have decreased, whereas turbidity of freshly squeezed turbid grape } \\
\text { juice (FSTGJ) was unchanged after the UV-C treatment. } \\
\text { Other physicochemical characteristics tested (pH, titratable acid, } \\
\text { total soluble solids content and color } L A B^{*} \text { ) were found unchanged } \\
\text { with the ultraviolet treatment. }\end{array}$ & [20] \\
\hline $\begin{array}{l}\text { Grape juice } \\
\text { (White) }\end{array}$ & UV-C dose $=0.90 \mathrm{~mL} / \mathrm{s}$ & $\begin{array}{l}\text { Significant change was detected on turbidity and browning index of } \\
\text { freshly squeezed white grape juice, whereas ascorbic acid was } \\
\text { found to decrease considerably. Color } L A B^{*} \text {, titratable acid and total } \\
\text { soluble solids content was found unchanged. } \\
\text { Yeasts, lactic acid bacteria, and aerobic plate count was found to } \\
\text { increase as storage life increased. The sample was found to spoil at } \\
\text { the 7th day. }\end{array}$ & [21] \\
\hline
\end{tabular}


Table 1. Cont.

\begin{tabular}{|c|c|c|c|}
\hline Medium & Variables & Effects & References \\
\hline \multirow{5}{*}{ Pineapple juice } & $\begin{array}{l}\text { UV-C dose }= \\
10.76 \mathrm{~mJ} / \mathrm{cm}^{2}\end{array}$ & $\begin{array}{l}\text { Turbidity, vitamin } \mathrm{C} \text {, and phenolic content were found to decrease, } \\
\text { whereas } \mathrm{pH} \text {, total soluble solids content, and titrable acidity had no } \\
\text { significant changes. }\end{array}$ & [22] \\
\hline & $\mathrm{UV}-\mathrm{C}$ dose $=7.5 \mathrm{~mJ} / \mathrm{cm}^{2}$ & $\begin{array}{l}\text { Total soluble solids lower than thermally treated juice in } 13 \text { weeks } \\
\text { of storage and decreased steadily in the seventh week onwards. } \\
\text { pH of UV-C-treated juice was higher than thermally treated juice. } \\
\text { Significant decrease of titratable acidity. } \\
\text { Ascorbic acid decreased significantly during the } 13 \text { weeks of storage. } \\
L^{*} \text { value was found higher and retained higher chroma value. } \\
\text { Turbidity was observed to increase significantly during storage time. } \\
\text { No significant changes were found on the total phenolic content but } \\
\text { decreased after the fifth week of storage. }\end{array}$ & [23] \\
\hline & $\begin{array}{l}\text { UV-C dose }=0.00154 \mathrm{~L} / \mathrm{s} \\
\text { for } 20-35 \mathrm{~s}\end{array}$ & $\begin{array}{l}\text { No significant effect was detected in } \mathrm{pH} \text {, total soluble solids content, } \\
\text { ascorbic acid content, } L^{*} \text { value. }\end{array}$ & [24] \\
\hline & $\begin{array}{l}\text { UV-C dose }= \\
10.76 \mathrm{~mJ} / \mathrm{cm}^{2}\end{array}$ & $\begin{array}{l}\text { No significant difference in the plastic viscosity between the } \\
\text { UV-C-irradiated and untreated juice at temperatures of } 5,10,15,20 \text {, } \\
\text { and } 25^{\circ} \mathrm{C} \text {. Thus, rheological attributes of UV-C-treated juice } \\
\text { were preserved. }\end{array}$ & [25] \\
\hline & $\begin{array}{l}\text { UV-C dose = } \\
53.42 \mathrm{~mJ} / \mathrm{cm}^{2}\end{array}$ & $\begin{array}{l}\text { Ascorbic acid, carotenoids, phenolic acids, and antioxidant capacity } \\
\text { were found to lower significantly after UV-C treatment, but were } \\
\text { significantly higher than the thermal treatment. Exception for } \\
\text { flavonoids, where the content is much lower than thermally } \\
\text { pasteurized juice. } \\
\text { Total phenolic contents and flavonoids were found to decrease } \\
\text { significantly throughout } 14 \text { days of storage. With the exception for } \\
\text { carotenoids, where it was found to increase within the } 14 \text { days } \\
\text { of storage. }\end{array}$ & [26] \\
\hline $\begin{array}{l}\text { Pummelo } \\
\text { (Citrus Grandis } \\
\text { L. Osbeck) juice }\end{array}$ & $\begin{array}{l}\text { UV-C dose }=15.45,18.18 \\
\text { and } 27.63 \mathrm{~mJ} / \mathrm{cm}^{2}\end{array}$ & $\begin{array}{l}\text { Significant decreases were observed on } \mathrm{pH} \text {, total soluble solids } \\
\text { content, ascorbic acid, total phenolic acid, and antioxidant activity. } \\
\text { However, clarity and color were detected to increase. }\end{array}$ & [27] \\
\hline Starfruit & $\mathrm{UV}-\mathrm{C}$ dose $=2.158 \mathrm{~J} / \mathrm{cm}^{2}$ & $\begin{array}{l}\text { No significant changes in } \mathrm{pH} \text { and total soluble solids content. } \\
\text { Significant decrease in the acidity. } \\
\text { An increase in } L^{*} \text { value but } a^{*} \text { and } b^{*} \text { seemed to decrease. } \\
\text { A non-significant increase in DPPH inhibition. } \\
\text { A significant decrease in vitamin C. }\end{array}$ & [28] \\
\hline \multirow{2}{*}{$\begin{array}{l}\text { Watermelon } \\
\text { juice }\end{array}$} & $\begin{array}{l}\mathrm{UV}-\mathrm{C} \text { dose }=2.4,4.8,7.3 \\
\quad \text { and } 9.7 \mathrm{~kJ} / \mathrm{L}\end{array}$ & $\begin{array}{l}\text { UV-C dose of } 4.8 \mathrm{~kJ} / \mathrm{L} \text { had reduced PME activity to } 75 \% \text { its original } \\
\text { content in } 5 \mathrm{~min} \text { of exposure in comparison to heat treatment at } \\
60^{\circ} \mathrm{C} \text { in } 20 \mathrm{~min} \text {. } \\
\text { Color } L^{*} \text { value was found to increase as UV-C dose increased. }\end{array}$ & [29] \\
\hline & $\begin{array}{l}\text { UV-C dose }=2.7,5.4,9.4 \\
\quad \text { and } 37.5 \mathrm{~mJ} / \mathrm{cm}^{2}\end{array}$ & $\begin{array}{l}\text { A significant increase was seen on } \mathrm{pH} \text { and total soluble solids } \\
\text { content after } 25 \text { days of storage. } \\
\text { No significant changes on the total phenolic content. } \\
\text { Total color change was seen to increase in accordance to increment } \\
\text { of UV-C doses. }\end{array}$ & [30] \\
\hline $\begin{array}{l}\text { Lemon-melon } \\
\text { juice mix }\end{array}$ & $\begin{array}{l}\text { UV-C dose = } \\
0.44-2.86 \mathrm{~J} / \mathrm{mL}\end{array}$ & $\begin{array}{l}\text { No significant changes detected on } \mathrm{pH} \text {, total soluble solids content, } \\
\text { total acidity, turbidity, and } L^{*} \text { value. Shelf life was increased from } \\
2 \text { days to } 30 \text { days. }\end{array}$ & [31] \\
\hline $\begin{array}{l}\text { Pomegranate } \\
\text { juice }\end{array}$ & $\mathrm{UV}-\mathrm{C}$ dose $=12-62 \mathrm{~J} / \mathrm{mL}$ & $\begin{array}{l}\text { No significant changes to total phenol content and TEAC values. } \\
\text { No significant changes in } \mathrm{pH} \text {, total soluble solids content, DPPH, } \\
\text { and titration acidity. }\end{array}$ & [32] \\
\hline
\end{tabular}

UV-C irradiation treatment aims to prolong the shelf life of food in addition to reduce health hazards associated with presence of pathogens while maintaining the natural nutritional components. Basic UV-C irradiation mechanisms involves photochemical reactions which can be initiated in two ways: (1) Direct reactions-absorption of a photon of light by a molecule can produce a chemical reaction and change its state. The extent of chemical reaction depends upon the quantum yield and fluence of incident photos. UV-C light at $257.3 \mathrm{~nm}$ has a radiant energy of $112.8 \mathrm{kcal} /$ Einstein, thus it is theoretically possible to affect the $\mathrm{O}-\mathrm{H}, \mathrm{C}-\mathrm{C}, \mathrm{C}-\mathrm{H}, \mathrm{C}-\mathrm{N}, \mathrm{H}-\mathrm{N}$, and S-S bonds, if UV-C light is absorbed [2]. (2) Photosensitized-the most common type of photosensitizing reaction is photo-oxidation. Photosensitizers are typically excited from the ground state to a short-lived singlet excited state that undergoes conversion to a long-lived triplet state that mediates the process. The triplet 
sensitizer can react further by two major pathways: by hydrogen- or electron-transfer processes, or by energy-transfer reactions [33].

Meanwhile, the effects on food quality are measured in two ways: (1) juice characteristics; and (2) sensorial. The former involves physical and chemical measurements including $\mathrm{pH}$, vitamins, polyphenols, color, and antioxidant activity, among others. While the latter involves an evaluation of organoleptic qualities or sensory evaluation of the food entailing taste, smell, appearance, and texture.

In general, there are no predictable effects of UV-C treatment on fruit juices as can be seen from Table 1. However, it can be concluded that the UV-C effect on liquid food is highly dependent on the amount of UV-C light absorbed by treated juice. Spikes [34] observed that at a wavelength specific for UV-C ( $257.3 \mathrm{~nm})$, compounds containing conjugated bonds, such as aromatic-ring and double-ring molecules, as well as compounds containing disulfide bonds were found to be effective UV-C light absorbers. He also stated in the same study that vitamin A, B2, B12, D, E, K, carotenes, folic acid, tryptophan, and unsaturated fatty acids are 'light-sensitive' and can degrade with the exposure of UV-C light. Vitamin C was also observed to be the strongest absorber of UV-C light, even at the lowest concentration. Fan and Geveke [11] in their study noted that the major components of fruit juice could also be the main cause of limited UV-C absorption. Sugars, such as fructose, sucrose, and glucose, were found to have high UV-C absorbance in the range of $240-360 \mathrm{~nm}$, where, fructose was found to be the highest UV-C absorbent at $260-280 \mathrm{~nm}$. Therefore, it is considered normal for a fruit juice with high vitamin $\mathrm{C}$, vitamin $\mathrm{A}$, and fructose contents to lose considerable amounts of its original content after being irradiated by UV-C light.

In a study by Falguera et al. [12], the loss of ascorbic acid was observed to be between $4 \%$ and $6 \%$ in the irradiation of apple juices of different varieties (Golden, Starking, and Fuji). Significant losses of ascorbic acid were found for the variety King David (70\%), even with the same processing conditions (120 min). Tran and Farid [9] irradiated orange juice with UV-C dose of $73.8 \mathrm{~mJ} / \mathrm{cm}^{2}$ had a degradation of ascorbic acid by $12 \%$. Ye et al. [35] had also found that $50 \%$ degradation of vitamin $C$ was found on commercially-made apple juice. These findings are similar to that found in thermal treatment, where Lopez et al. [36] reported $12 \%$ to $21 \%$ loss of ascorbic acid during thermal treatment of $10 \mathrm{~min}$. A significant decrease of $19.5 \%$ of ascorbic acid in a study by Shamsudin et al. [22] of UV-C treated pineapple juice further confirmed the findings of Davey et al. [37] which stated that the reduction of ascorbic acid content can be attributed to the oxidation process together with the activities of ascorbate oxidase and peroxidase enzymes, which can also affect the phenolic and antioxidant compounds within the UV-C treated juice.

These reductions of vitamin $C$ were also blamed for lessening pigmentation in the juice, where it was observed by Koutchma et al. [2] that certain food pigments are light sensitive. Falguera et al. [12] stated that melanins and melanoidins contained in fruit derivatives are polymeric compounds that can degrade to a brown coloration, which is detrimental to sensory quality. Melanins were also touted to be the protective shield for various enzymes from UV-C irradiation [38]. However, for fruit juice with absent or degraded melanins, the luminosity (or color $L^{*}$ value) is expected to increase, thus exaggerating the reduction of vitamin $C$. This observation is consistent with the results from Shah et al. [27], Chia et al. [23] and Bhat et al. [28], where the $L^{*}$ value of treated pummelo (Citrus Grandis L. Osbeck), pineapple, and starfruit juice was found to increase, indicating that the pigments and browning coloration (or perhaps to be more specific, polyphenol oxidase enzyme) was destroyed by UV-C irradiation, whereas the vitamin $C$ of each fruit juice was found to decrease significantly. As proved in a study of UV-C treated mango nectar, the color of the juice concentrates maintained for 26 days as polyphenol oxidase enzyme was observed to decrease to $5-\log _{10}$ reduction [4].

The denaturation of enzymes in fruit juice was also highlighted by several studies. Naturally occurring enzymes in fruit juice play an important role in assessing the shelf life of those juices. Enzymes that were found in abundant in fruit juices are; polyphenol oxidase (PPO)—protein that causes the enzymatic browning, pectic enzymes; such as pectin methylesterase (PME) and polygalacturonase-proteins that are responsible in causing "cloud-loss" in fruit juice. Inactivation 
of these enzymes is crucial in order to prolong the shelf-life of juice. Seiji and Iwashita [38] have reported that polyphenol oxidase, ATPase, and acid phosphatase molecules may be denatured when irradiated by UV-C light. The loss of enzymes is highly dependent on the intensity of UV-C irradiation as highlighted by Falguera et al. [12], where PME, PPO, and peroxidase in apple juice was completely inactivated after 100 and $15 \mathrm{~min}$, respectively. Zhang et al. [29], in their study of watermelon juice, found 75\% reduction of PME, whereas, Tran and Farid [9] had a 5\% reduction on PME of orange juice. Contrarily, Muller et al. [19] and Shah et al. [27] found no significant effect on enzyme activity was detected in UV-C irradiated apple juice and pummelo (Citrus Grandis L. Osbeck) juice. Both studies had perused dean vortex UV-C technology and it is unclear if this reactor had limited the UV-C emission. As stated by Falguera et al. [12], a wider emission spectrum of UV-C should be applied in order to effectively inactivate these enzymes.

Carbohydrates, were not affected by UV-C irradiation, specifically. However, singlet oxygen and hydroxyl radicals can produce some sensitized photoreactions, which can result in the photochemical depolymerization of polysaccharides in foods, producing softening in fruit pulp, which may be the main reason for decrement of turbidity in some fruit juice. Muller et al. [19], Kaya and Unluturk [20], Unluturk and Atilgan [21], and Shamsudin et al. [22], had observed that the turbidity of the treated fruit juice (apple and grape juice, white grape juice, and pineapple juice, respectively) had decreased significantly, altering the absorption coefficient for each juice.

UV-C reactor types were also theorized to have a consequence towards the physicochemical changes of fruit juice treated. Koutchma et al. [2] had stated that, in order to achieve $5 \log _{10}$ microbial reduction, critical factors include the transmissivity of the product, geometric configurations of the reactor, power, wavelength, and physical arrangement of the UV-C sources, the product profile and the radiation path length are imperative and must not be overlooked. For the UV-C pasteurization to be effective (with minimal path length), specific optimization of the model system has to be made to the selected juice. It was asserted by Orlowska et al. [15] that Taylor-couette UV-C unit producing 4.45 to $13.34 \mathrm{~mJ} / \mathrm{cm}^{2}$ had a significant effect towards viscosity, turbidity, and polyphenol oxidase (PPO) of apple juice. These significant changes were presumed to be attributed with the fluid-mechanical sensitivity of plant tissues [39]. The superposition of laminar axial flow $(1500 \mathrm{~mL} / \mathrm{min})$ and circular flow (200 rpm) in an annulus resulted in the formation of turbulent vortices' flow. Under such condition, the apple particles encountered the shear forces associated with the flow gradients of the parallel laminar layers and centrifugal forces generated by the counter-rotating helical vortices. Due to the disruptive effects of the hydrodynamical stresses, the biological tissues are fragmented and content of small particles increases.

Whereas, in a study by Muller et al. [19], UV-C inactivation of apple and grape juice utilizing a coiled tube UV-C reactor, with UV-C dose of $4.02 \mathrm{~kJ} / \mathrm{L}$, reductions of PPO, color $L^{*}$ value, and viscosity were again significant. These effects were again presumed to be caused due to pumping and flow conditions in the reactor with absorption coefficient of each juice played a supplemental factor. The highest effect of UV-C on PPO activity was in apple juice $\left(\alpha=52.4 \mathrm{~cm}^{-1}\right)$, followed by grape juice $\left(\alpha=43.4 \mathrm{~cm}^{-1}\right)$ and can be explained by the attenuation of UV-C energy due to the absorption of soluble compounds in apple and grape juices as well as by the lower mixing efficiency in the juice $\left(\operatorname{Re}_{\mathrm{AJ}}=1002, \operatorname{Re}_{\mathrm{GJ}}=1015\right)$. However, studies by Caminiti et al. [13] and Falguera et al. [12] utilizing vertical concentric tubes and collimated beam apparatus, respectively had shown no significant effects in the total phenol content, $\mathrm{pH}$, soluble solids content, and titratable acidity. It is thus advised to optimize the reactor specification (flow rate, velocity or even the gap width) to be optimized to ascertain that the juice is effectively pasteurized with minimal changes to the juice quality.

Shelf life of UV-C irradiated fruit juice is highly depended on the amount of polyphenol, ascorbic acid, and sugar left within the juice, coupled with the amount of pertinent microorganisms found in the fruit juice during a standard 12-weeks storage. These are naturally decaying properties of juice being kept at $4{ }^{\circ} \mathrm{C}$ (standard chiller temperature). While minimal studies have been reported on shelf life of UV-C irradiated fruit juice, it was found that Tandon et al. [16] in his study perusing CiderSURE had noted that the quality of apple cider did not maintain after one week of storage, whereas, orange juice treated with a minimal dosage of $73.8 \mathrm{~mJ} / \mathrm{cm}^{2}$ was found to extend to only five 
days [9]. Contrarily, in a study by Kaya et al. [31] on UV-C irradiated lemon-melon juice mix with UV-C dose of 0.44 to $2.86 \mathrm{~J} / \mathrm{mL}$, was prolonged the shelf-life of the juice from 2 to 30 days, with very little significant changes on the physicochemical characteristics of the juice, with the exception of turbidity. Decrement of turbidity throughout the storage of lemon-melon juice mix was theorized on the lack of microbial growth and inactivation of proteins and polyphenol complexes [40]. Shah et al. [27] in her study of UV-C treated pummelo (Citrus Grandis L. Osbeck) fruit juice had found that the juice is able to withstand up to six weeks in comparison to less than one week for freshly-squeezed non-pasteurized pummelo (Citrus Grandis L. Osbeck) fruit juice. This assumption was based on the minimum requirement of ascorbic acid of $0.25 \mathrm{mg} / \mathrm{mL}$ [41].

In general, different juice types with varying nutritional and physicochemical contents can result in different ranges of absorption coefficient which subsequently, absorb varying amounts of UV-C doses to significantly change their physicochemical characteristics. Thus, limitation towards exposure of UV-C is crucial in order to avoid overexposure to the UV-C light which may lead to adverse effects on the quality and nutritional values of fruit juices.

\section{Sensory Properties of UV-C-Irradiated Juices}

Sensory quality of fruit juices plays an important role in consumer satisfaction. Most studies reported that UV-C treated juices were not significantly different than fresh juices but were significantly different from heat treated juices (Table 2). The pasteurized samples were significantly less preferred for odor, color, cloudiness, acidity, overall flavor and overall likeness than the control and UV-C-treated samples [17]. After non-thermal treatments, juice samples exhibited the lowest variation in hedonic scores, when compared to the control [42,43]. Panelists rated non-thermal-treated juices as 'like slightly' for color, odor and taste. Correspondingly, Hazila et al. [44] reported slightly rancid smell of UV-C treated pitaya juice while significantly lower hedonic scores for flavor and aroma of UV-C processed orange juice was reported by Pala and Toklucu [32]. In addition, the development of browning compounds due to UV-C photo-degradation may cause a decrease in hedonic scores $[13,28,29,45]$.

Table 2. Sensory properties of UV-C-irradiated fruit juices.

\begin{tabular}{|c|c|c|c|}
\hline Juice Type & Irradiation Condition & Observation & References \\
\hline Apple juice & $\begin{array}{l}\text { UV-C dose = } \\
2.66-53.10 \mathrm{~J} / \mathrm{cm}^{2}\end{array}$ & $\begin{array}{l}\text { Sensory evaluation showed that samples treated with energy } \\
\text { dosages up to } 10.62 \mathrm{~J} / \mathrm{cm}^{2} \text { were comparable to the control in terms } \\
\text { of acceptability, though higher dosages produced adverse effects in } \\
\text { terms of flavor and color. }\end{array}$ & [13] \\
\hline \multirow{3}{*}{ Apple cider } & $\mathrm{UV}-\mathrm{C}$ dose $=14 \mathrm{~mJ} / \mathrm{cm}^{2}$ & $\begin{array}{l}\text { UV-C-treated apple cider was found to be at par with } \\
\text { flash-pasteurized and hot-filled apple cider. However, the ranking } \\
\text { preference decreased as storage week increased. }\end{array}$ & [16] \\
\hline & $\mathrm{UV}-\mathrm{C}$ dose $=\mathrm{NA}$ & $\begin{array}{l}\text { Consumer acceptability study showed no significant difference } \\
\text { between untreated cider samples and UV-C-pasteurized samples. }\end{array}$ & [17] \\
\hline & $\begin{array}{l}\text { UV-C dose }= \\
17.55 \mathrm{~mJ} / \mathrm{cm}^{2}\end{array}$ & $\begin{array}{l}\text { The triangle test indicated non-significant differences between } \\
\text { untreated and UV-C-treated apple cider. }\end{array}$ & [18] \\
\hline Orange juice & UV-C dose $=12-48 \mathrm{~kJ} / \mathrm{L}$ & $\begin{array}{l}\text { Triangle test indicated a significant difference between UV-C and } \\
\text { heat treated orange juice in terms of overall flavor and aroma } \\
\text { characteristics. UV-C-treated orange juice was found to have an } \\
\text { overall score of } 4.1 \text { and } 3.8 \text { for flavor and aroma attributes, ranking } \\
\text { it as "neither like nor dislike". }\end{array}$ & [10] \\
\hline Mango juice & $\begin{array}{l}\text { UV-C treatment (for } 15 \text {, } \\
30 \text { and } 60 \mathrm{~min} \text { at } 25^{\circ} \mathrm{C} \text { ) }\end{array}$ & $\begin{array}{l}\text { The sensory evaluation verified that non-thermal-treated juice was } \\
\text { preferred more than thermally-treated juice. }\end{array}$ & [42] \\
\hline Pineapple juice & $\mathrm{UV}-\mathrm{C}$ dose $=\mathrm{NA}$ & UV-C treated juices were preferred to thermally pasteurized juice. & [43] \\
\hline $\begin{array}{l}\text { Blend of orange } \\
\text { and carrot }\end{array}$ & $\begin{array}{c}\text { UV-C dose }=10.6 \mathrm{~J} / \mathrm{cm}^{2} \\
\text { or high intensity light } \\
\text { pulses }(\mathrm{HILP})\left(3.3 \mathrm{~J} / \mathrm{cm}^{2}\right. \\
\text { combined with } \\
\text { manothermosonication } \\
\text { technology }(400 \mathrm{kPa}, \\
\left.35^{\circ} \mathrm{C}, 1000 \mathrm{~W}, 20 \mathrm{kHz}\right)\end{array}$ & $\begin{array}{l}\text { The juice processed by UV-C + MTS was the most preferred } \\
\text { samples in terms of flavor ( } 4.8) \text { and was not significantly different } \\
\text { from the pasteurized samples. }\end{array}$ & [46] \\
\hline $\begin{array}{l}\text { Guava and } \\
\text { passion fruit } \\
\text { nectar }\end{array}$ & $\begin{array}{l}\mathrm{UV}-\mathrm{C} \text { dose }= \\
6.2-23.6 \mathrm{~J} / \mathrm{mL}\end{array}$ & $\begin{array}{l}\text { Significant differences were found for both nectars as panellists } \\
\text { describing changes of colors and aroma with metallic flavor, which } \\
\text { might indicate lipid oxidation. }\end{array}$ & [47] \\
\hline
\end{tabular}




\section{Safety of UV-C-Irradiated Fruit Juices}

\subsection{Microbiological Safety}

UV-C light has broad antimicrobial action, providing effective inactivation of viruses, vegetative bacteria, bacterial spores, yeasts, conidia, and parasites. UV-C light potential in obliterating bacteria, viruses and molds has been documented by many researchers (Table 3). However, the effect of UV-C radiation on microorganisms varies from inter-species, intra-species, strain, medium, density and even their size. Furthermore, the ability of UV-C inhibiting bacteria's replication is due to dimerization of their thymine bases in the DNA strands [48] which is limited to the ability of the UV-C irradiation to penetrate the liquid food. In fruit juices, $90 \%$ of UV-C irradiation is absorbed in the first 1-mm from the surface [49]. Moreover, researchers have reported varied power levels, process times, UV-C light source-product distances, and product thickness to achieve varied inactivation levels in many pathogens, had resulted various effects on the juice quality.

Table 3. Effects of UV-C irradiation on fruit juice microflora.

\begin{tabular}{|c|c|c|c|c|}
\hline Juices & Microflora & UV-C Dosage & Log Reduction & References \\
\hline Mango nectar & Aerobic plate count & $45 \mathrm{~J} \mathrm{~cm}^{-2}$ & 2.7 & [4] \\
\hline \multirow{3}{*}{ Pineapple juice } & $\begin{array}{l}\text { Aerobic plate count } \\
\text { Yeast and mold }\end{array}$ & $\begin{array}{l}10.76 \mathrm{~mJ} \mathrm{~cm}^{-2} \\
10.76 \mathrm{~mJ} \mathrm{~cm}^{-2}\end{array}$ & $\begin{array}{l}1.9 \\
1.4\end{array}$ & [22] \\
\hline & S. typhimurium & $0.000154 \mathrm{~L} \mathrm{~s}^{-1}$ & 3.0 & [24] \\
\hline & $\begin{array}{l}\text { Aerobic plate count } \\
\text { Yeast and mold }\end{array}$ & $\begin{array}{l}1607.0 \mathrm{~J} \mathrm{~L}^{-1} \\
1607.0 \mathrm{~J} \mathrm{~L}^{-1}\end{array}$ & $\begin{array}{l}<1.0 \\
<1.0\end{array}$ & {$[50]$} \\
\hline $\begin{array}{c}\text { Pummelo (Citrus Grandis L. } \\
\text { Osbeck) juice }\end{array}$ & S. typhimurium & $15.45-27.63 \mathrm{~mJ} \mathrm{~cm}^{-2}$ & $5.23-9.10$ & [27] \\
\hline Starfruit juice & Aerobic plate count & NA & total inactivation & [28] \\
\hline Lemon-melon juice mix & E. coli $\mathrm{K} 12$ & $0.44-2.86 \mathrm{~mJ} \mathrm{~cm}^{-2}$ & $0.06-6 \log$ & {$[31]$} \\
\hline \multirow{3}{*}{ Apple cider } & E. coli $\mathrm{O} 157: \mathrm{H7}$ & $4.45,6.67,13.34 \mathrm{~mJ} \mathrm{~cm}^{-2}$ & $2.85-4.76$ & {$[15]$} \\
\hline & $\begin{array}{l}\text { Aerobic plate count } \\
\text { Yeast and mold }\end{array}$ & $\begin{array}{l}14 \mathrm{~mJ} \mathrm{~cm}^{-2} \\
14 \mathrm{~mJ} \mathrm{~cm}^{-2}\end{array}$ & $\begin{array}{l}1.8 \\
1.4\end{array}$ & [16] \\
\hline & $\begin{array}{l}\text { E. coli } \mathrm{O} 157: \mathrm{H7} \\
\quad \text { E. coli } \mathrm{K} 12 \\
\text { E. coli } \mathrm{O} 157: \mathrm{H7} \\
\text { E. coli } \mathrm{O} 157: \mathrm{H} 7 \\
\text { E. coli } \mathrm{O} 157: \mathrm{H} 7\end{array}$ & $\begin{array}{c}8.77-35.11 \mathrm{~mJ} \mathrm{~cm}^{-2} \\
19.4 \mathrm{~mJ} \mathrm{~cm}^{-2} \\
14.0 \mathrm{~mJ} \mathrm{~cm} \\
0.1 \mathrm{~mJ} \mathrm{~cm}^{-2} \\
34.0 \mathrm{~J} \mathrm{~cm}^{-2}\end{array}$ & $\begin{array}{l}>5.0 \\
<2.0 \\
7.2 \\
5.4 \\
4.7\end{array}$ & $\begin{array}{l}{[18]} \\
{[51]} \\
{[52]} \\
{[53]} \\
{[54]}\end{array}$ \\
\hline \multirow{9}{*}{ Apple juice } & L. innocua & $2.7 \mathrm{~J} \mathrm{~cm}^{-2}$ & $4.8-5.8$ & [13] \\
\hline & $\begin{array}{c}\text { E.coli } \\
\text { S. cerevisiae } \\
\text { L. plantarum } \\
\text { A. acidoterrestris }\end{array}$ & $\begin{array}{l}7.7 \mathrm{~kJ} \mathrm{~L}^{-1} \\
9.6 \mathrm{~kJ} \mathrm{~L}^{-1} \\
3.9 \mathrm{~kJ} \mathrm{~L}^{-1} \\
9.6 \mathrm{~kJ} \mathrm{~L}^{-1}\end{array}$ & $\begin{array}{c}6.0 \\
4.0 \\
>5.0 \text { (total inactivation) } \\
4.0\end{array}$ & [14] \\
\hline & E. coli $\mathrm{K} 12$ & $24.9 \mathrm{~mJ} \mathrm{~cm}^{-2}$ & $>5.0$ & {$[51]$} \\
\hline & E. coli O157:H7 & 5,25 and $75 \mathrm{~mJ} \mathrm{~cm}^{-2}$ & $\begin{array}{l}2.81(\text { at } 222 \mathrm{~nm}) \\
1.95(\text { at } 254 \mathrm{~nm}) \\
1.83(\text { at } 282 \mathrm{~nm})\end{array}$ & [55] \\
\hline & $\begin{array}{l}\text { A. acidoterrestris } \\
\text { E.coli } \mathrm{O} 157: \mathrm{H} 7\end{array}$ & $\begin{array}{c}0.38-1.31 \mathrm{~mW} \mathrm{~cm}^{-2} \\
\text { NA }\end{array}$ & $\begin{array}{c}2.3 \\
2.76\end{array}$ & $\begin{array}{l}{[56]} \\
{[57]}\end{array}$ \\
\hline & $\begin{array}{c}\text { E.coli STCC } 4201 \\
\text { E. coli STCC } 471 \\
\text { E. coli STCC } 27325 \\
\text { E. coli O157:H7 } \\
\text { E. coli ATCC } 25922\end{array}$ & $\begin{array}{l}2.66 \mathrm{~mJ} \mathrm{~cm}^{-2} \\
2.66 \mathrm{~mJ} \mathrm{~cm}^{-2} \\
2.66 \mathrm{~mJ} \mathrm{~cm}^{-2} \\
2.66 \mathrm{~mJ} \mathrm{~cm}^{-2} \\
2.66 \mathrm{~mJ} \mathrm{~cm}^{-2}\end{array}$ & $\begin{array}{l}1.23 \\
1.64 \\
2.36 \\
4.01 \\
6.22 \\
\end{array}$ & {$[58]$} \\
\hline & Zygosaccharomyces bailii & $26.4 \mathrm{~kJ} \mathrm{~m}^{-2}$ & 5.0 & [59] \\
\hline & $\begin{array}{c}\text { E. coli } \\
\text { L. brevis } \\
\text { S. cerevisiae }\end{array}$ & $\begin{array}{l}6-24 \mathrm{~mJ} \mathrm{~cm}^{-2} \\
6-24 \mathrm{~mJ} \mathrm{~cm}^{-2} \\
6-24 \mathrm{~mJ} \mathrm{~cm}^{-2}\end{array}$ & $\begin{array}{c}6.0 \\
5.75 \\
4.0\end{array}$ & {$[60]$} \\
\hline & E. coli & NA & $>5.0$ & [61] \\
\hline
\end{tabular}


Table 3. Cont.

\begin{tabular}{|c|c|c|c|c|}
\hline Juices & Microflora & UV-C Dosage & Log Reduction & References \\
\hline \multirow{5}{*}{ Apple juice } & Aerobic plate count & $230.0 \mathrm{JL}^{-1}$ & 3.5 (total inactivation) & \multirow{3}{*}{ [50] } \\
\hline & Yeast and mold & $230.0 \mathrm{~J} \mathrm{~L}^{-1}$ & 3.0 (total inactivation) & \\
\hline & E. coli $\mathrm{K} 12$ & $1377.0 \mathrm{~J} \mathrm{~L}^{-1}$ & $>7.0$ & \\
\hline & $\begin{array}{l}\text { S. cerevisiae } \\
\text { L. monocytogenes }\end{array}$ & $1100 \mu \mathrm{W} \mathrm{cm}{ }^{-2}$ & $\begin{array}{l}5.0 \\
4.0\end{array}$ & [62] \\
\hline & E. coli O157:H7 & $300.0 \mathrm{~mJ} \mathrm{~cm}^{-2}$ & 4.5 & [63] \\
\hline \multirow{2}{*}{ Apple and cranberry juice } & P. fermentans & $5.3 \mathrm{~J} \mathrm{~cm}^{-2}$ & $<2.0$ & \multirow{2}{*}{ [64] } \\
\hline & E. coli & $5.3 \mathrm{~J} \mathrm{~cm}^{-2}$ & 6.0 & \\
\hline \multirow{3}{*}{ Grape juice } & S. cerevisiae & $138 \mathrm{~mJ} \mathrm{~cm}{ }^{-2}, 9 \mathrm{~min}$ & 5 & \multirow{3}{*}{ [20] } \\
\hline & Yeasts & $280 \mathrm{~mJ} \mathrm{~cm}^{-2}, 24 \mathrm{~min}$ & 3 & \\
\hline & Lactic acid bacteria & $280 \mathrm{~mJ} \mathrm{~cm}^{-2}, 24 \mathrm{~min}$ & 4.3 & \\
\hline \multirow{4}{*}{ Grape juice (White) } & E. coli $\mathrm{K} 12$ & $0.90 \mathrm{~mL} \mathrm{~s}^{-1}$ & 5.2 & [21] \\
\hline & A. acidoterrestris & $0.38-1.31 \mathrm{~mW} \mathrm{~cm}^{-2}$ & 5.8 & [56] \\
\hline & B. bruxellensis & $1377.0 \mathrm{~J} \mathrm{~L}^{-1}$ & $>5.0$ & \multirow{2}{*}{ [65] } \\
\hline & S. cerevisiae & $3672.0 \mathrm{~J} \mathrm{~L}^{-1}$ & $>5.0$ & \\
\hline \multirow{2}{*}{ Grapefruit juice } & E.coli & $19.0 \mathrm{~mJ} \mathrm{~cm}^{-2}$ & 5.1 & \multirow{2}{*}{ [66] } \\
\hline & S. cerevisiae & $14.0 \mathrm{~mJ} \mathrm{~cm}^{-2}$ & 6.0 & \\
\hline \multirow{3}{*}{ Grape juice (Red) } & B. bruxellensis & $3672.0 \mathrm{~J} \mathrm{~L}^{-1}$ & 2.0 & \multirow{3}{*}{ [65] } \\
\hline & S. cerevisiae & $3672.0 \mathrm{~J} \mathrm{~L}^{-1}$ & $>5.0$ & \\
\hline & L. plantarum & $3672.0 \mathrm{~J} \mathrm{~L}^{-1}$ & $>5.0$ & \\
\hline \multirow{4}{*}{ Pomegranate juice } & E. coli & $62.4 \mathrm{~J} \mathrm{~mL}^{-1}$ & 6.2 & \multirow{4}{*}{ [32] } \\
\hline & Aerobic plate count & $62.4 \mathrm{~J} \mathrm{~mL}^{-1}$ & 1.8 & \\
\hline & Yeast and mold & $62.4 \mathrm{~J} \mathrm{~mL}^{-1}$ & 1.5 & \\
\hline & Yeast and mold & NA & 4.0 & \\
\hline Watermelon juice & Aerobic plate count & $2.7-37.5 \mathrm{~J} \mathrm{~m} \mathrm{~L}^{-1}$ & 1.5 & [30] \\
\hline \multirow{2}{*}{ Passion fruit } & Aerobic plate count & NA & 0.53 & \multirow{2}{*}{ [47] } \\
\hline & Yeast and mold & NA & total inactivation & \\
\hline \multirow{2}{*}{ Guava nectar } & Aerobic plate count & NA & 0.51 & \multirow{2}{*}{ [47] } \\
\hline & Yeast and mold & NA & 1.36 & \\
\hline Guava-and-nineannle iuice & Yeast and mold & $918.0 \mathrm{~J} \mathrm{~L}^{-1}$ & 4.5 (total inactivation) & \\
\hline Guava-and-pineapple juice & Aerobic plate count & $1377.0 \mathrm{~J} \mathrm{~L}^{-1}$ & 3.3 & [50] \\
\hline \multirow{5}{*}{ Orange juice } & L. plantarum & $9.6 \mathrm{~kJ} \mathrm{~L}^{-1}$ & 5.0 & [14] \\
\hline & E. coli O157:H7 & $36.1 \mathrm{~kJ} \mathrm{~L}^{-1}$ & 5.7 & [10] \\
\hline & Aerobic plate count & $1607.0 \mathrm{~J} \mathrm{~L}^{-1}$ & $<1.0$ & \multirow{2}{*}{ [50] } \\
\hline & Yeast and mold & $1607.0 \mathrm{~J} \mathrm{~L}^{-1}$ & $<1.0$ & \\
\hline & E. coli $\mathrm{O} 157: \mathrm{H7}$ & $2.2 \mathrm{~J} \mathrm{~cm}^{-2}$ & $>5.0$ & [67] \\
\hline Pitaya juice & Z. bailii & $1.0 \mathrm{~kJ} \mathrm{~m}^{-2}$ & 1.8 & [68] \\
\hline
\end{tabular}

UV-C light acts as the oxidizing agent inducing the formation of highly reactive hydroxyl radicals [69]. This radical formation and subsequent reaction on cell components is positively influenced by temperature and the optimal temperature is $50{ }^{\circ} \mathrm{C}$ [70]. DNA (deoxyribonucleic acid) consists of a sequence of four constituent bases known as purines (adenine and guanine) and pyrimidines (thymine and cytosine). They are linked together in a double-stranded helix. When UV-C radiation is absorbed by the pyrimidine bases, it permits a unique photochemical reaction, which leads to dimerization of adjacent pyrimidines (formation of chemical bond between the pyrimidines). Most of the time, the dimerization happens with thymines but cytosine dimmers and thymine-cytosine heterodimers can also be formed. This disruption in the structure of the DNA makes it unable to replicate when the cell undergoes mitosis [71]. At higher doses $\left(>1000 \mathrm{~mJ} / \mathrm{cm}^{2}\right)$ UV-C light can also affect the capsid proteins. The combined effect of size/type of the virion and nucleic acids are thought to be factors determining the resistance/sensitivity of viruses towards UV-C [72].

UV-C fluency is dictated by the absorption coefficient and path length of the specific fruit juice. These parameters can be influenced by two main factors; (1) the liquid food characteristics, where turbidity, particle size, viscosity, total soluble solids, suspended solids, and-sometimes- $\mathrm{pH}$. These characteristics play an important role in dictating the amount of UV-C light to be absorbed. Compared to water, liquid foods have a range of optical and physical properties as well as diverse 
chemical compositions [12]; Whereas factor (2) involves the type of UV-C reactor used to photosensitize the juice, which subsequently will influence UV-C light transmittance, dose delivery, momentum transfer, and-consequently-microbial inactivation [33]. These factors will subsequently influence the amount of photo-oxidation incident within the treated juice.

Foremost, a clear understanding of UV-C influence rate on the relationship between absorption coefficient of liquid food, interference from particulates and soluble and suspended solid, is critical to produce effective UV-C pasteurization. This theory was also reported by Guerrero-Beltran and Barbosa-Canovas [4] and Koutchma et al. [2] where, product composition, solid contents, color and overall chemistry of the food product were found to have a major impact on both the absorption coefficient and UV-C inactivation effectiveness. Fruit juices with different turbidity, total soluble solids, and $\mathrm{pH}$ levels as well as varying viscosities significantly distinguish the approaches to treat them successfully using UV-C light. Suspended solids cannot only attenuate the UV-C dose via light scattering, but may also provide a site for the aggregation of bacteria to the particle's surface [2]. Hence, the variations and combinations of physical properties of juice such as turbidity and particle size, cannot be overlooked.

Absorption coefficients of juices are highly dictated by the component inside the juice. Shah et al. [27] in her study observed that absorption coefficient of juice is correlated to the turbidity and total soluble solids, which further affect the particle size distribution in the juice. Juice particle size made up of soluble and suspended solids have high light absorbance and have an opaque characteristic to light unless they have high porosity. However, porosity can harbor microorganisms, allowing them to survive or partially injured during UV-C processing. Whereas, turbidity of juice is determined by the content of suspended solid (or juice matters and pulp), will highly influence the viscosity attributes of the juice. The increment of viscosity or flowability of the juice will subsequently increase the flow rate of the juice inside the UV-C reactor. Higher flow rates resulted in increased mixing and more sufficient irradiation of juice. Decreasing the turbidity of juice will positively influence the effectiveness of UV-C inactivation, resulting in a higher inactivation rate.

On the contrary, Muller et al. [14] had reported that blood orange juice with the highest turbidity (9986 NTU), viscosity (2.74 mPa.s) and linearly correlated to absorption coefficient of $194.3 \mathrm{~cm}^{-1}$ had higher inactivation rate of L. plantarum in blood orange juice than in naturally cloudy apple juice with absorption coefficient of $48.4 \mathrm{~cm}^{-1}$. In another study done by Koutchma [73], using a coiled UV-C module, the absorption coefficient of juices seems to have a significant effects towards E. coli $\mathrm{K} 12$ inactivation. However, with value of absorption coefficient of more than $48 \mathrm{~cm}^{-1}$, the inactivation was reported to have less than $1 \log _{10}$ reduction with one pass through the UV-C reactor. The $\log _{10}$ reduction can be increased if the passes are to be increased, exposing the juice to higher UV-C light energy to inactivate the pathogens. E. coli K12 inactivation in apple cider $\left(\alpha=57 \mathrm{~cm}^{-1}\right.$, turbidity $=1383 \mathrm{NTU}$ ) confirmed this observation when only $1 \log _{10}$ reduction was obtained after six passes through the reactor at a flow rate of $75 \mathrm{~L} / \mathrm{min}$.

Pass length and the amount of UV-C absorbed by the fruit juice can maximized the UV-C lethality towards microorganisms. The latest development on dean vortex had proven that inactivation of pertinent microbes can be done even with the most opaque liquid foods. Choudhary et al. [74] in his works had proven to successfully inactivate $5 \log _{10}$ count of E. coli and B. cereus in raw and skimmed cow milk. The effectiveness of the reactor was due to high and rapid turbulent (high Reynolds number) formed within the coiled tube reactor while minimizing the path length (or the gap width) of the liquid food sample and UV-C emission. The same technology was replicated by Muller et al. [14] and Shah et al. [27] where it was also proven that the coiled reactor managed to inactivate up to $5 \log _{10}$ bacterial count of A. acidoterretris, E. coli, L. plantarum, and S. cerevisiae and S. typhimurium.

\subsection{Chemical Safety}

Recently, furan was highlighted as one of the main concern in utilizing UV-C irradiation on fruit juice [75]. Furan is a heterocyclic aromatic compound containing one oxygen atom and a suspected 
carcinogenic by IARC with Group 2B classification, which is stated as "possibly carcinogenic to humans" [76]. Furan does not have a practical application as a final product. However, it plays a role in the production of (co)polymers and furan has been identified in a number of food that have been heat treated [77] and recently, in UV-C-treated fruit juice [11]. Literatures containing furan as part of the safety analysis involving UV-C irradiation is very limited to the ones reported in Table 4.

Table 4. Effect of UV-C irradiation on furan content in fruit juice.

\begin{tabular}{|c|c|c|c|}
\hline Medium & Variables & Effects & References \\
\hline Apple juice & $\begin{array}{l}\text { UV-C dose = } \\
10 \mathrm{~mW} / \mathrm{cm}^{2}\end{array}$ & $\begin{array}{l}\text { Minimal of furan at dose less than } 3.5 \mathrm{~J} / \mathrm{cm}^{2} \text {. } \\
\text { At } 8.8 \mathrm{~J} / \mathrm{cm}^{2}, \sim 14 \mathrm{ppb} \text { furan was formed. Furan } \\
\text { formation increased at a rate of } 11 \mathrm{ppb} \text { per } \mathrm{J} / \mathrm{cm}^{2}\end{array}$ & [11] \\
\hline $\begin{array}{l}\text { Pummelo } \\
\text { (Citrus Grandis } \\
\text { L. Osbeck) juice }\end{array}$ & $\begin{array}{l}\text { UV-C dose = } \\
15.45,18.18 \text { and } \\
27.63 \mathrm{~mJ} / \mathrm{cm}^{2}\end{array}$ & $\begin{array}{l}\text { Furan development depended on UV-C dose } \\
(0.66-2.4 \mathrm{ppb} / \mathrm{mL}) \text { and inversely proportional } \\
\text { towards the sugar content of the juice. Furan was } \\
\text { also seen to decrease as the storage weeks increased. }\end{array}$ & [27] \\
\hline Apple juice & $\begin{array}{c}\text { UV-C dose = } \\
39-245 \mathrm{~mJ} / \mathrm{cm}^{2}\end{array}$ & $\begin{array}{l}\text { Furan increased from } 2.3 \text { to } 3.7 \mu \mathrm{g} / \mathrm{kg} \text { proportional } \\
\text { to increment of UV-C dose. No significant increase } \\
\text { was found when freshly squeezed and commercial } \\
\text { apple juices were compared. }\end{array}$ & [14] \\
\hline $\begin{array}{l}\text { Apple juice } \\
\text { and cider }\end{array}$ & $\begin{array}{c}\text { UV-C dose = } \\
3.1-6.3 \mathrm{~mJ} / \mathrm{cm}^{2}\end{array}$ & $\begin{array}{l}\text { Content of fructose and malic acid in the juice was } \\
\text { shown to have induced the furan formation. } \\
\text { Apple juice was found to have high furan content in } \\
\text { comparison to apple cider. }\end{array}$ & [78] \\
\hline
\end{tabular}

In addition to that, furan was found to form from carbohydrates, ascorbic acid, fatty acids, and a mixture of all three $[79,80]$. Both literatures have claimed that furan formation is highly associated with the physicochemical properties of fruit juice, where fructose was found to be the main cause. The simple sugars can be grouped into two types according to the ring structures: five-member furanoses (furan like) and six-member pyranoses (such as glucose). The furanoses are less stable upon heating than pyranoses. For example, glucose can be heated up to $100{ }^{\circ} \mathrm{C}$, but sucrose and fructose decomposes at a temperature as low as $60^{\circ} \mathrm{C}$ [81]. It was also found that the reduction rate of furan during storage, is slower as the UV-C fluence decreased [27]. The same observation was found in a study of furan formation upon gamma irradiation during 14-day storage at $5{ }^{\circ} \mathrm{C}$ [80]. The rapid destruction by high-dose of UV-C may also contribute to the initial boost in the accumulation of furan occurring in the tested samples, mostly due to the high amount of sugar. Hence, cautions should be made when fruit juice with a high content of fructose being treated with UV-C irradiation to avoid excessive formation of furan.

The finding of Shah et al. [27], however, was found to be unexpectedly higher than the results reported by Fan and Geveke [11], where it was shown that $8.8 \mathrm{~J} / \mathrm{cm}^{2}$ (equivalent to $8800 \mathrm{~mJ} / \mathrm{cm}^{2}$ )

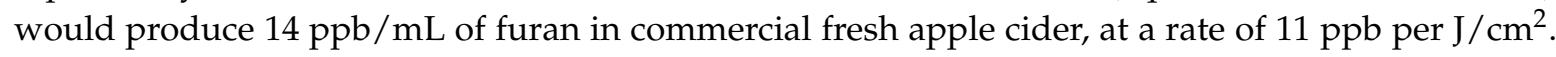
The authors also claimed that significant amount of furan could be accumulated if the fruit juice was over-treated [11]. Comparing to the results of Bule et al. [81], the amount of furan found in apple juice treated with UV-C fluence rate of $5.94 \mathrm{~mJ} / \mathrm{cm}^{2}$ was $1648 \mathrm{ppb} / \mathrm{mL}$. Both literatures have claimed that furan formation is highly associated with the physicochemical properties of fruit juice, where fructose was found to be the main cause.

Temperature of UV-C reactor was also found to be one of the main causes of furan formation. As the results of Shah et al. [27] were considered highest in comparison to the other researchers (Table 4), where the rate furan formation was found to be $1 \mathrm{ppb}$ to every $20^{\circ} \mathrm{C}$ increment, whereas, Fan and Geveke [11] reported a furan formation rate of $1 \mathrm{ppb}$ to every $28^{\circ} \mathrm{C}$ increment. Nevertheless, the FDA [82] survey reported that furan levels in some thermally processed juices were in the range of 2.5-8.4 ppb/mL and furan formation in UV-C irradiated juices are well below the thermally processed juice. 


\section{Hurdle Technology of UV-C-Irradiated Fruit Juices}

Due to certain limitations that the UV-C technology possesses, the application is often combined with other processing techniques to achieve maximal benefits in microbial reduction and retention of juice quality. There is much to be explored with regards to the use of hurdle technology in UV-C processing of juices. The combination could be between UV-C technology and heat or it could be between UV-C and other nonthermal methods (nonthermal technologies or application of chemicals and preservatives). Juices tested using the hurdle technology includes apple, pineapple, guava, orange, pitaya, mango, watermelon, and mixed juices. Several combinations which have been explored for ultraviolet irradiation of juices includes sonication, mild heat, dimethyl dicarbonate, acids, membrane filtration, $\mathrm{TiO}_{2}-\mathrm{UVC}$ (TUVP) photocatalysis, preservatives, and pulsed electric field (Table 5). Some combinations were able to achieve the required 5-log reduction of microorganisms and some failed to do so. Some combined treatments has the potential to significantly reduce a variety of pathogens, spores, yeasts, molds, and protozoa. The combined membrane filtration and UV achieved more than a 5-log reduction of E. coli, C. parvum, and A. acidoterrestris [83]. Gram-negative bacteria, E. coli O157:H7, S. typhimurium, and S. cerevisiae counts were significantly reduced after a combined treatment using TUVP and high pressure [84]. Combined treatment extended the shelf life of juices $[64,85]$. In some cases, synergistic microbial inactivation effects of the combined treatments were observed [85-88] while in other cases, undesirable flavor of the end products were reported [13,42].

Table 5. Effect of UV-C irradiation and hurdle technology on juice.

\begin{tabular}{|c|c|c|c|}
\hline Juice Type & Combined Treatments & Irradiation Effect on Juice Properties & References \\
\hline $\begin{array}{l}\text { Apple (Jonagold } \\
\text { Red) juice }\end{array}$ & $\begin{array}{l}\text { UV-C treatment (for } 30 \mathrm{~min} \text { ) and } \\
\text { pulsed electric field treatment at } \\
40 \mathrm{kV} / \mathrm{cm} \text { for } 100 \text { pulses }\end{array}$ & $\begin{array}{l}\text { Obtained satisfactory total microbial } \\
\text { inactivation and improved product quality } \\
\text { compared to heat pasteurization. }\end{array}$ & [5] \\
\hline Mango juice & $\begin{array}{l}\text { (i) Combined sonication, } 15 \mathrm{~min} \text { and } \\
\text { UV-C treatment, } 15 \mathrm{~min} \\
\text { (ii) Combined sonication, } 30 \mathrm{~min} \text { and } \\
\text { UV-C treatment, } 15 \mathrm{~min} \\
\text { (iii) Combined sonication, } 15 \mathrm{~min} \text { and } \\
\text { UV-C treatment, } 30 \mathrm{~min} \\
\text { (iv) Combined sonication, } 30 \mathrm{~min} \text { and } \\
\text { UV-C treatment, } 30 \mathrm{~min}\end{array}$ & $\begin{array}{l}\text { Support the use of nonthermal treatments } \\
\text { (ultrasound and UV-C) for better retention } \\
\text { of quality and prolonged shelf life in } \\
\text { Chokanan mango juice processing. }\end{array}$ & [42] \\
\hline $\begin{array}{l}\text { Orange and carrot } \\
\text { mix juice }\end{array}$ & $\begin{array}{l}\text { UV-C treatment }\left(10.6 \mathrm{~J} / \mathrm{cm}^{2}\right) \text { or high } \\
\text { intensity light pulses (HILP) } \\
\left(3.3 \mathrm{~J} / \mathrm{cm}^{2} \text { combined with }\right. \\
\text { manothermosonication technology } \\
\left(400 \mathrm{kPa}, 35^{\circ} \mathrm{C}, 1000 \mathrm{~W}, 20 \mathrm{kHz}\right)\end{array}$ & $\begin{array}{l}\text { Panelists did not perceive differences in the } \\
\text { odor, sweetness, or acidity of the product. }\end{array}$ & [46] \\
\hline \multirow[t]{2}{*}{ Apple juice } & $\begin{array}{l}\text { UV-C treatment (NA) and radio } \\
\text { frequency electric field (RFEF) } \\
(20 \mathrm{kHz})\end{array}$ & $\begin{array}{l}\text { Highly depended on the temperature } \\
\text { increment }\left(25,30 \text { and } 40^{\circ} \mathrm{C}\right) \text { during UV-C } \\
\text { and RFEF-treatment which reduced the } \\
\text { E. coli log count to } 4,3.3 \text {, and } 1.5 \\
\text { respectively. However, the injured } \\
\text { population of } E \text {. coli was seen the lowest } \\
\text { with UV-C treatment }(4 \%) \text { alone in } \\
\text { comparison to RFEF treatment }(84 \%) \text {. }\end{array}$ & {$[61]$} \\
\hline & $\begin{array}{l}\text { UV-C treatment }(13.81-5.20 \mathrm{~J} / \mathrm{mL}) \text { at } \\
\text { mild heat }\left(45-60^{\circ} \mathrm{C}\right)\end{array}$ & $\begin{array}{l}\text { S. cerevisiae showed the highest resistance } \\
\text { towards UV-C + heat treatment. As the } \\
\text { inactivation of S. cerevisiae was limited due } \\
\text { to its relatively high absorption coefficient. } \\
\text { The combination of UV-C treatment and } \\
\text { heat between } 52.5 \text { and } 57.5^{\circ} \mathrm{C} \text { led to a } \\
\text { synergistic effect of inactivating } S \text {. cerevisae. }\end{array}$ & [86] \\
\hline
\end{tabular}


Table 5. Cont.

\begin{tabular}{|c|c|c|c|}
\hline Juice Type & Combined Treatments & Irradiation Effect on Juice Properties & References \\
\hline \multirow{4}{*}{ Apple juice } & $\begin{array}{l}\text { UV-C treatment (for } 1.8 \mathrm{~s} \text { ) and pulsed } \\
\text { electric fields (PEF) }(60 \mathrm{kV} / \mathrm{cm})\end{array}$ & $\begin{array}{l}\text { Additive effect of PEF and UV-C treatment } \\
\text { on } E \text {. coli microbial population. } \\
\text { No significant effect was found on the } \\
\text { physicochemical characteristics of apple } \\
\text { juice treated with HILP and PEF. }\end{array}$ & [89] \\
\hline & $\begin{array}{l}\text { Pulsed light }\left(2.4-71.6 \mathrm{~J} / \mathrm{cm}^{2}\right) \text { and } \\
\text { ultrasound }(20 \mathrm{kHz}, 95.2 \mu \mathrm{m})\end{array}$ & $\begin{array}{l}\text { The application of } 30 \mathrm{~min} \text { of ultrasound } \\
\text { followed by } 60 \mathrm{~s} \text { of pulsed light with the } \\
\text { final temperature of } 56^{\circ} \mathrm{C} \text { was the most } \\
\text { effective, with reduction of } 6.4 \text { and } 5.8 \log _{10} \\
\text { of } S \text {. cerevisiae in commercial and natural } \\
\text { squeezed apple juice. }\end{array}$ & [90] \\
\hline & $\begin{array}{l}\text { High intensity light pulses (HILP) } \\
\left(4-5.1 \mathrm{~J} / \mathrm{cm}^{2}\right) \text { and pulsed electric } \\
\text { fields }(\mathrm{PEF})(130-262 \mathrm{~J} / \mathrm{mL})\end{array}$ & $\begin{array}{l}\text { The combination of PEF and HILP resulted } \\
\text { in } 7 \log _{10} \text { reduction of } E \text {. coli while the } \\
\text { reversed of HILP and PEF only resulted in } \\
5 \log _{10} \text { reduction of } E \text {. coli. }\end{array}$ & [91] \\
\hline & $\begin{array}{l}\text { UV-C treatment (UV-C; } 30 \mathrm{~min}, 20^{\circ} \mathrm{C} \text { ) } \\
\text { pre-heating and pulsed electric } \\
\text { fields (PEF) }\end{array}$ & $\begin{array}{l}\text { Reduced S. aureus in apple juice by up to } \\
9.5 \text { log10. Preheating temperatures had } \\
\text { non-significant effects on reduction of } \\
\text { S. aureus, while treatment time and electric } \\
\text { field strength significantly affected bacterial } \\
\text { reduction in apple juice. }\end{array}$ & [92] \\
\hline Apple (Fuji) juice & $\begin{array}{l}\text { UV-C treatment }(27.10 \mathrm{~J} / \mathrm{mL}) \text { and heat } \\
\left(55.0^{\circ} \mathrm{C} \text {, and } 3.58 \mathrm{~min}\right)\end{array}$ & $\begin{array}{l}\text { Bactericidal effect of UV-C light on E. coli } \\
\text { suspended in apple juice synergistically } \\
\text { increases with temperature and achieved } \\
5 \log _{10} \text { reductions without affecting pH, } \\
\text { total soluble solids, and acidity of freshly } \\
\text { squeezed apple juice. }\end{array}$ & [87] \\
\hline \multirow[t]{2}{*}{ Pineapple juice } & $\begin{array}{l}\text { UV-C treatment }\left(10.76 \mathrm{~mJ} / \mathrm{cm}^{2}\right) \text { and } \\
\text { dimethyl dicarbonate }(\mathrm{DMDC} \\
250 \mathrm{ppm})\end{array}$ & $\begin{array}{l}\text { Turbidity, vitamin C, and phenolic content } \\
\text { were found to have significant } \\
\text { changes-the decrements were } \\
\text { considerable in comparison to repetitive } \\
\text { UV-C-treatment. The order of DMDC } \\
\text { addition to the sample was shown to have } \\
\text { significant effect towards total plate count } \\
\text { (TPC) and yeast and mold (YMC). }\end{array}$ & [22] \\
\hline & $\begin{array}{l}\text { Mild heat }\left(55^{\circ} \mathrm{C}, 10 \mathrm{~min}\right) \text { followed by } \\
\text { UV-C treatment }\left(5.61 \mathrm{~mJ} / \mathrm{cm}^{2}\right)\end{array}$ & $\begin{array}{l}\text { Effectively inactivate the pectin } \\
\text { methylesterase in pineapple juice, } \\
\text { preserved relatively high amount of } \\
\text { bromelain and total phenol content. }\end{array}$ & [85] \\
\hline Peach nectar & $\begin{array}{l}\text { UV-C treatment and Potassium } \\
\text { Sorbate }(250,500,1000 \text {, and } 2000 \mathrm{ppm}) \\
\text { UV-C treatment and Sodium Benzoate } \\
(250,500,1000 \text {, and } 2000 \mathrm{ppm})\end{array}$ & $\begin{array}{l}\text { Potassium sorbate absorbs light close to the } \\
\text { shortwave ultraviolet germicidal } \\
\text { wavelength, thus, it can only be added after } \\
\text { the UV-C treatment. } \\
\text { The synergistic effect of UV-C and sodium } \\
\text { benzoate was shown to have up to } 3.5 \log _{10} \\
\text { reduction of A. niger and A. flavus. }\end{array}$ & [88] \\
\hline Green guava juice & $\begin{array}{l}\text { UV-C treatment }\left(3.47 \mathrm{~mJ} / \mathrm{cm}^{2}\right) \\
\text { followed by mild heat }\left(55^{\circ} \mathrm{C}, 60 \mathrm{~s}\right)\end{array}$ & $\begin{array}{l}\text { Achieved } 5 \log _{10} \text { reduction of L. innocua, } \\
\text { retained acceptable } \\
\text { physicochemical properties. }\end{array}$ & [93] \\
\hline \multirow[t]{2}{*}{ Orange juice } & $\begin{array}{l}\text { UV-C treatment }(23.72 \mathrm{~J} / \mathrm{mL}) \text { and heat } \\
\left(55.0^{\circ} \mathrm{C} \text {, and } 3.6 \mathrm{~min}\right)\end{array}$ & $\begin{array}{l}\text { Achieved more than } 5 \log _{10} \text { cycles of } E . \text { coli } \\
\text { inactivation without affecting the pH, } \\
\text { acidity, total soluble solids, and color. } \\
\text { However, ascorbic acid content was } \\
\text { decreased by } 16.45 \% \text { and } 63.96 \% \text { of } \\
\text { pectinmethylesterase activity. }\end{array}$ & [94] \\
\hline & $\begin{array}{l}\text { UV-C treatment }\left(0-18.7 \mathrm{~kJ} / \mathrm{m}^{2}\right) \text { and } \\
\text { ultrasonic }(20 \mathrm{kHz}, 95.2 \mu \mathrm{m})\end{array}$ & $\begin{array}{l}\text { Simultaneous used of both technologies for } \\
20 \text { min yielded the highest reduction of } \\
\text { E. coli in orange juice (3.4), in comparison to } \\
\text { separate treatment of ultrasonic and } \\
\text { ultraviolet (2.0). }\end{array}$ & [95] \\
\hline
\end{tabular}


Table 5. Cont.

\begin{tabular}{|c|c|c|c|}
\hline Juice Type & Combined Treatments & Irradiation Effect on Juice Properties & References \\
\hline Red pitaya juice & $\begin{array}{l}\text { UV-C treatment, citric acid }(1.5 \%) \text { and } \\
\text { dimethyl dicarbonate }(15 \mu \mathrm{L} / 100 \mathrm{~mL})\end{array}$ & $\begin{array}{l}\text { Addition of } 1.5 \% \text { citric acid and dimethyl } \\
\text { dicarbonate into red pitaya juice prior to } \\
\text { UV-C treatment achieved significantly } \\
\text { higher microbial reduction compared to } \\
\text { UV-C alone. }\end{array}$ & {$[44]$} \\
\hline \multirow[b]{2}{*}{$\begin{array}{l}\text { Apple and } \\
\text { cranberry juice }\end{array}$} & $\begin{array}{l}\text { (i) UV-C treatment }\left(5.3 \mathrm{~J} / \mathrm{cm}^{2}, 30 \mathrm{~s}\right) \\
\text { and pulsed electric fields }(34 \mathrm{kV} / \mathrm{cm} \text {, } \\
93 \mu \mathrm{s}) \text {; } \\
\text { (ii) UV-C treatment }\left(5.3 \mathrm{~J} / \mathrm{cm}^{2}, 30 \mathrm{~s}\right) \\
\text { and manothermosonication }(20 \mathrm{kHz} \text {, } \\
750 \mathrm{~W}, 400 \mathrm{kPa})\end{array}$ & $\begin{array}{l}\text { More than } 6 \log _{10} \text { reduction of E. coli } \mathrm{K} 12 \\
\text { and Pichia fermentans in fresh blend of apple } \\
\text { cranberry juice was found for both } \\
\text { combinations of ultraviolet and PEF/MTS. } \\
\text { Storage time was extended to } 15 \text { days for } \\
\text { the juice sample after treated with UV-C } \\
\text { and PEF. }\end{array}$ & {$[64]$} \\
\hline & $\begin{array}{l}\text { (i) UV-C treatment }\left(5.3 \mathrm{~J} / \mathrm{cm}^{2}\right) \text { and } \\
\text { pulsed electric fields }(34 \mathrm{kV} / \mathrm{cm} \text {, } \\
93 \mu \mathrm{s}) \text {; } \\
\text { (ii) UV-C treatment }\left(5.3 \mathrm{~J} / \mathrm{cm}^{2}\right) \text { and } \\
\text { manothermosonication }(20 \mathrm{kHz} \text {, } \\
750 \mathrm{~W}, 400 \mathrm{kPa})\end{array}$ & $\begin{array}{l}\text { The combination of UV-C and PEF did not } \\
\text { cause considerable changes in } \mathrm{Lab}^{*} \text { color } \\
\text { and total phenolics content in comparison } \\
\text { to the combination treatment of UV-C and } \\
\text { manothermosonication (MTS) with } \\
\text { exception towards non-enzymatic } \\
\text { browning index, where non-significant } \\
\text { effect detected. The overall acceptability of } \\
\text { UV-C and PEF was the highest among other } \\
\text { non-thermal combinations. UV-C and MTS } \\
\text { was ranked the lowest for the unfavorable } \\
\text { flavor of the sample. }\end{array}$ & [91] \\
\hline $\begin{array}{l}\text { Red and yellow } \\
\text { Watermelon juice }\end{array}$ & UV-C treatment and citric acid (1.5\%) & Did not achieve $5 \log _{10}$ reduction & {$[96]$} \\
\hline
\end{tabular}

Physico-chemical and functional properties of juices treated with a combination of UV-C and other microbial reducing methods were not significantly affected $[13,22,88,93]$. Shelf life of the juice was also extended and in treatments where mild heat was involved enzyme activity were mostly halted [84]. In one instance UV-C and mild heat combination effectively inactivated the pectin methylesterase in pineapple juice, but preserved relatively high amount of bromelain and total phenol content [84].

A hurdle technology approach must be an intelligent approach so not to affect quality of the product. The intensity of treatment and order of the combined treatments would affect the end results. Whether to apply UV-C as a pre-treatment process or apply another technique before UV-C exposure that is a question which has varying answers, depending on the combinations applied. For example, the order of dimethyl dicarbonate addition (before or after UV-C exposure) to the sample was shown to have significant effect towards total plate count and yeast and mold count [22]. A combination of UV-C and sonication of mango juice was found to decrease the overall acceptability which could be attributed to the formation of free radicals induced by sonication, thus causing an off-flavor of the juices [42].

\section{Market Potential and Cost Implications}

Juices treated with UV-C when compared with thermally treated juice, has relatively better taste, color profile, and ascorbic acid content, similar to that of the freshly pressed juice $[17,43]$. A good product can only be launched to reach its target consumers with the aid of a suitable and fitting marketing strategy [97]. When a product produced is of premium quality (better color and flavor profile, higher nutrient retention, and fresh-like characteristics) the selling price could be set at a relatively higher value. Through a survey done, it was reported that consumers especially those who are health conscious will be willing to spend money for premium products thus creating better profitability value [98]. UV-C irradiated juice is perceived as a premium product due to its proven superior quality [97]. UV-C irradiated juice obtained a considerably higher perceived positioning compared to the different commercialized brands, which were largely thermally treated. UV-C pasteurization is a low-cost alternative to thermal pasteurization for small processing operations $[17,18,98-100]$. 
The estimated cost of an ultraviolet irradiation equipment is only USD 10,000 to USD 15,000 compared to USD 20,000 to USD 30,000 for thermal pasteurization equipment [100,101]. Energy requirement for UV-C pasteurization is cheaper than thermal pasteurization energy requirement for both technologies and this has been pointed out by several researchers $[9,98,99]$. The variable cost for UV-C treated pineapple juice is RM 0.895 per can $(320 \mathrm{~mL})$ while thermally treated pineapple juice is RM 0.900 per can $(320 \mathrm{~mL})$. These results indicate that UV-C pasteurization could produce juice at a lower production cost than thermal pasteurization [98]. Similar observations were reported for apple cider where UV-C pasteurization costs are approximately RM 1.60 per 100 liters [102] and thermal pasteurization costs is approximately RM 4.00 per 100 liters [101].

The fact that consumers are willing to pay more for UV-C treated juices is good news for small scale manufacturers. The fact that implementation of UV-C technology can be more profitable than heat treatment when applied in a small-to-medium scale pineapple juice processing plant is more good news for small scale manufacturers. The profitability index for both investments predicts high profitability, but UV-C technology offers excellent investment potential and shorter payback period. A profitability index of 21.56 and payback period of four months for UV-C treated pineapple juice can be considered attractive in comparison to thermally treated pineapple juice, where the profitability index is only 17.10 and the payback period is 30 days longer [98]. However, despite the market potential for UV-C treated fruit juice, it should be reiterated that UV-C does impart a negative effect towards fruit juice, as such mentioned in Section 4.2 on the furan development of fruit juice, especially on citrus juice. It is therefore recommended that fruit manufacturers establish the correct UV dose and control it during juice exposure to UV-C and regularly test that the amount of furan developed to be within the limits allowed by USFDA $[8,75]$.

\section{Summary}

Fruit juices treated with UV-C $(253.7 \mathrm{~nm})$ have potential and demand in the industry. Although UV-C is still an unfamiliar process to the industry, it is of significance in the production of safe, fresh-like, minimally-altered juice products that are easily degraded by conventional heat treatments. Due to certain limitations of the UV technology, attempts have been made to combine ultraviolet with other processes at low intensities. This is an alternative which could lead to significant benefits in maintaining juice quality. However, it must be done correctly to ensure the required safe limit and quality preferences are met, through appropriate control the dosage and exposure of UV-C to the fruit juice. Positioning of UV-C treated juices as a premium product with relatively lower investment costs and a quicker payback period could be attractive for small scale manufacturers. It is clear that UV-C technology has its place in the juice industry and is definitely an option for juice manufacturers. However, it is important to note that this paper did not cover the aspect of UV-C equipment design and cost implications of combining UV-C technology with other methods. It is also recommended that the current status of regulation in various countries pertaining to the use of UV-C technology for juice production is reviewed and documented.

Acknowledgments: The authors would like to acknowledge Nor Hasni Hambali for the technical support.

Conflicts of Interest: the authors declare no conflict of interest.

\section{References}

1. Huang, S. Global Trade Patterns in Fruits and Vegetables. Agriculture and Trade Report No. WRS-04-06. Available online: http://www.errds/usda-gov/publications/WRS0406/wrs0406dfm.pdf (accessed on 9 November 2011).

2. Koutchma, T.; Forney, L.J.; Moraru, C.I. Ultraviolet Light in Food Technology: Principles and Applications; CRC Press: Boca Raton, FL, USA, 2009.

3. Koutchma, T. Advances in ultraviolet light technology for non-thermal processing of liquid foods. Food Bioprocess Technol. 2009, 2, 138-155. [CrossRef] 
4. Guerrero-Beltrán, J.A.; Barbosa-Cánovas, G.V. Inactivation of Saccharomyces cerevisiae and polyphenoloxidase in mango nectar treated with UV light. J. Food Prot. 2006, 69, 362-368. [PubMed]

5. Noci, F.; Riener, J.; Walkling, M.; Cronin, D.A.; Morgan, D.J.; Lying, J.G. Ultraviolet irradiation and pulsed electric fields (PEF) in a hurdle strategy for the preservation of fresh apple juice. J. Food Eng. 2008, 85, 141-146. [CrossRef]

6. Koutchma, T.; Popović, V.; Ros-Polski, V.; Popielarz, A. Effects of ultraviolet light and high-pressure processing on quality and health-related constituents of fresh juice products. Compr. Rev. Food Sci. Food Saf. 2016. [CrossRef]

7. Harm, W. Biological Effects of Ultraviolet Radiation; Cambridge University Press: New York, NY, USA, 1980.

8. US Food and Drug Administration (USFDA). Available online: http://www.ars.usda.gov/main/site_main. htm?modecode=12-35-45-00 (accessed on 14 November 2011).

9. Tran, M.T.T.; Farid, M. Ultraviolet treatment of orange juice. Innov. Food Sci. Emerg. Technol. 2004, 5, 495-502. [CrossRef]

10. Pala, C.U.; Toklucu, A.K. Microbial, physicochemical and sensory properties of UV-C processed orange juice and its microbial stability during refrigerated storage. LWT Food Sci. Technol. 2013, 50, 426-431. [CrossRef]

11. Fan, X.; Geveke, D.J. Furan formation in sugar solution and apple cider upon ultraviolet treatment. J. Agric. Food Chem. 2007, 55, 7816-7821. [CrossRef] [PubMed]

12. Falguera, V.; Pagán, J.; Ibarz, A. Effect of UV-C irradiation on enzymatic activities and physicochemical properties of apple juices from different varieties. LWT Food Sci. Tech. 2011, 44, 115-119. [CrossRef]

13. Caminiti, I.M.; Palgan, I.; Muñoz, A.; Noci, F.; Whyte, P.; Morgan, D.J.; Lyng, J.G. The effect of ultraviolet light on microbial inactivation and quality attributes of apple juice. Food Bioprocess Technol. 2012, 5, 680-686. [CrossRef]

14. Müller, A.; Stahl, M.R.; Graef, V.; Franz, C.M.A.P.; Huch, M. UV-C treatment of juices to inactivate microorganisms using dean vortex technology. J. Food Eng. 2011, 107, 268-275. [CrossRef]

15. Orlowska, M.; Koutchma, T.; Kostrzynska, M.; Tang, J.; Defelice, C. Evaluation of mixing flow conditions to inactivate Escherischia coli in opaque liquids using pilot-scale Taylor-Couette UV-C unit. J. Food Eng. 2014, 120, 100-109. [CrossRef]

16. Tandon, K.; Worobo, R.W.; Churey, J.J.; Padilla-Zakour, O.I. Storage quality of pasteurized and UV-C treated apple cider. J. Food Process. Preserv. 2002, 27, 21-35. [CrossRef]

17. Choi, L.H.; Nielsen, S.S. The effects of thermal and nonthermal processing methods on apple cider quality and consumer acceptability. J. Food Qual. 2005, 28, 13-29. [CrossRef]

18. Donahue, D.W.; Canitez, N.; Bushway, A.A. UV-C inactivation of E. coli O157:H7 in apple cider: Quality, sensory \& shelf-life analysis. J. Food Process. Preserv. 2004, 28, 368-387.

19. Müller, A.; Noack, L.; Greiner, R.; Stahl, M.R.; Posten, C. Effect of UV-C and UV-B treatment on polyphenol oxidase activity and shelf life of apple and grape juices. Innov. Food Sci. Emerg. Technol. 2014, 26, 498-504. [CrossRef]

20. Kaya, Z.; Unluturk, S. Processing of clear and turbid grape juice by a continuous flow UV-C system. Innov. Food Sci. Emerg. Technol. 2015, 33, 282-288. [CrossRef]

21. Unluturk, S.; Atilgan, M.R. Microbial safety and shelf life of UV-C treated squeezed white grape juice. J. Food Sci. 2015, 80, 1831-1841. [CrossRef] [PubMed]

22. Shamsudin, R.; Noranizan, M.A.; Yap, P.Y.; Mansor, A. Effect of repetitive ultraviolet irradiation on the physico-chemical properties and microbial stability of pineapple juice. Innov. Food Sci. Emerg. Technol. 2014, 10, 166-171. [CrossRef]

23. Chia, S.L.; Rosnah, S.; Noranizan, M.A.; Wan Ramli, W.D. The effect of storage on the quality attributes of ultraviolet-irradiated and thermally pasteurized pineapple juice. Int. Food Res. J. 2012, 19, 1001-1010.

24. Mansor, A.; Shamsudin, R.; Mohd Adzahan, N.; Hamidon, M.N. Efficacy of ultraviolet radiation as a non-thermal treatment for the inactivation of Salmonella typhimurium TISTR 292 in pineapple fruit juice. Agric. Agric. Sci. Proced. 2014, 2, 173-180. [CrossRef]

25. Shamsudin, R.; Chia, S.L.; Mohd Adzahan, N.; Wan Daud, W.R. Rheological properties of ultraviolet-irradiated and thermally pasteurized Yankee pineapple juice. J. Food Eng. 2013, 116, 548-553. [CrossRef] 
26. Goh, S.G.; Noranizan, M.; Leong, C.M.; Sew, C.C.; Sobhi, B. Effect of thermal and ultraviolet treatments on the stability of antioxidant compounds in single strength pineapple juice throughout refrigerated storage. Int. Food Res. J. 2012, 19, 1131-1136.

27. Shah, N.N.A.K.; Rahman, R.A.; Shamsudin, R.; Adzahan, N.M. Furan development in Dean Vortex UV-CC treated pummelo (Citrus Grandis L. Osbeck) fruit juice. In Proceedings of the International Conference on Sustainable Agriculture for Food, Energy and Industry in Regional and Global Context, Serdang, Malaysia, 25-27 August 2015.

28. Bhat, R.; Ameran, S.; Han, C.V.; Karim, A.A.; Liong, M.T. Quality attributes of starfruit (Averrhoa carambola L.) juice treated with ultraviolet radiation. Food Chem. 2011, 127, 641-644. [CrossRef] [PubMed]

29. Zhang, C.; Trierweiler, B.; Li, W.; Butz, P.; Xu, Y.; Rufer, C.E.; Ma, Y.; Zhao, X. Comparison of thermal, ultraviolet-c, and high pressure treatments on quality parameters of watermelon juice. J. Food Control 2011, 126, 254-260. [CrossRef]

30. Feng, M.; Ghafoor, K.; Seo, B.; Yang, K.; Park, J. Effects of ultraviolet-C treatment in Teflon coil on microbial populations and physic-chemical characteristics of watermelon juice. Innov. Food Sci. Emerg. Technol. 2013, 9, 133-139. [CrossRef]

31. Kaya, Z.; Semanur, Y.; Unluturk, S. Effect of UV-C-C irradiation and heat treatment on the shelf life of a lemon-melon juice blend; multivariate statistical approach. Innov. Food Sci. Emerg. Technol. 2015, 29, $230-239$. [CrossRef]

32. Pala, C.U.; Toklucu, A.K. Effect of UV-C on anthocyanin content and other quality parameters of pomegranate juice. J. Food Comp. Anal. 2011, 24, 790-795. [CrossRef]

33. Gomez-Lopez, V.M.; Koutchma, T.; Linden, K. Ultraviolet and pulsed light processing of fluid foods. In Novel Thermal and Non-Thermal Technologies for Fluid Foods; Cullen, P.J., Tiwai, B., Valdramidis, V., Eds.; Academic Press: San Diego, CA, USA, 2012; pp. 185-223.

34. Spikes, J. Photodegradation of foods and beverages. In Photochemical and Photobiological Reviews Volume 6; Plenum Press: New York, NY, USA, 1981; pp. 39-81.

35. Ye, Z.; Koutchma, T.; Parisi, B.; Larkin, J.; Forney, J.E. Ultraviolet inactivation kinetics of E. coli and Y. pseudotuberculosis in annular reactors. J. Food Sci. 2007, 72, 271-278. [CrossRef] [PubMed]

36. Lopez, A.; Krehl, W.A.; Good, E. Influence of time and temperature on ascorbic acid stability. J. Am. Diet. Assoc. 1967, 50, 308-310. [PubMed]

37. Davey, M.W.; Van Montagu, M.; Inze, D.; Sanmartin, M.; Kanellis, A.; Smimoff, N.; Benzie, L.J.J.; Strain, J.J.; Favell, D.; Fletcher, J. Plant L-ascorbic: Chemistry, function, metabolism, bioavailable and effects of processing. J. Sci. Food Agric. 2000, 80, 825-860. [CrossRef]

38. Seiji, M.; Iwashita, S. Enzyme inactivation by ultraviolet light and protective effect of melanin. J. Biochem. 1965, 57, 457-459. [PubMed]

39. Kieran, P.M.; MacLoughlin, P.F.; Malone, D.M. Plant cell suspension cultures: Some engineering considerations. J. Biotech. 1997, 59, 39-52. [CrossRef]

40. Lee, H.S.; Coates, G.A. Effect of thermal pasteurization on Valencia orange juice color and pigments. Food Sci. Technol. 2003, 36, 153-156. [CrossRef]

41. Ting, S.V. Nutrients and nutrition of citrus fruits. In Citrus Nutrition and Quality; Nagy, S., Attaway, J.A., Eds.; American Chemical Society: Washington, DC, USA, 1980; pp. 3-24.

42. Santhirasegaram, V.; Razali, Z.; George, D.S.; Chandran, S. Effects of Thermal and Non-thermal Processing on Phenolic Compounds, Antioxidant Activity and Sensory Attributes of Chokanan Mango (Mangifera indica L.) Juice. Food Bioprocess Technol. 2015, 8, 2256-2267. [CrossRef]

43. Hanisah, H. Effect of Ultraviolet Irradiation on the Quality of Pineapple Juice. Bachelor's Thesis, Universiti Putra Malaysia, Serdang, Selangor, Malaysia, 2009.

44. Halim, H.; Noranizan, M.; Sobhi, B.; Sew, C.C.; Karim, R.; Osman, A. Nonthermal pasteurization of pitaya (Hylocereus polyrhizus) juice using the hurdle concept. Int. Food Res. J. 2012, 19, 1457-1461.

45. Vercet, A.; Lopez, P.; Burgos, J. Free radical production bymanothermosonication. Ultrasonics 1998, 36, 615-618. [CrossRef]

46. Caminiti, I.M.; Noci, F.; Morgan, D.J.; Cronin, D.A.; Lyng, J.G. The effect of pulsed electric fields, ultraviolet light or high intensity light pulses in combination with manothermosonication on selected physico-chemical and sensory attributes of an orange and carrot juice blend. Food Bioprod. Process 2012, 90, 442-448. [CrossRef] 
47. Guevara, M.; Tapia, M.S.; Gomez-Lopez, V.M. Microbial inactivation and quality of guava and passion fruit nectars treated by UV-C light. Food Bioprocess Technol. 2012, 5, 803-807. [CrossRef]

48. Mukhopadhyay, S.; Ramaswamy, R. Application of emerging technologies to control Salmonella in foods: A review. Food Res. Int. 2012, 45, 666-677. [CrossRef]

49. Sizer, C.E.; Balasubramaniam, V.M. New intervention processes for minimally processed juices. Food Technol. 1999, 53, 64-67.

50. Keyser, M.; Muller, I.A.; Cilliers, F.P.; Nel, W.; Gouws, P.A. Ultraviolet radiation as a non-thermal treatment for the inactivation of microorganisms in fruit juice. Innov. Food Sci. Emerg. Technol. 2008, 9, 348-354. [CrossRef]

51. Koutchma, T.; Parisi, B. Biodosimetry of Escherichia coli UV-C inactivation in model juices with regard to dose distribution in annular UV-C reactors. J. Food Sci. 2004, 69, 14-22.

52. Basaran, N.; Quintero-Ramos, A.; Maoke, M.M.; Churey, J.J.; Worobo, R.W. Influence of apple cultivars on inactivation of different strains of Escherischia coli O157:H7 in apple cider by UV-C irradiation. Appl. Environ. Microbiol. 2004, 70, 6061-6065. [CrossRef] [PubMed]

53. Wright, J.R.; Sumner, S.S.; Hackney, C.R.; Pierson, M.D.; Zoecklein, B.W. Efficacy of ultraviolet light for reducing Escherichia coli O157:H7 in unpasteurized apple cider. J. Food Protect. 2000, 63, 563-567.

54. Geveke, D.J. UV inactivation of bacteria in apple cider. J. Food Protect. 2005, 68, 1739-1742.

55. Yin, F.; Zhu, Y.; Koutchma, T.; Gong, J. Inactivation and potential reactivation of pathogenic Escherichia coli O157:H7 in apple juice following ultraviolet exposure at three monochromatic wavelength. Food Microbiol. 2014. [CrossRef] [PubMed]

56. Baysal, A.; Molva, C.; Unluturk, S. UV-C light inactivation and modeling kinetics of Alicyclobacillus acidoterrestris spores in white grape and apple juices. Int. J. Food Microbiol. 2013, 166, 494-498. [CrossRef] [PubMed]

57. Gabriel, A.A. Inactivation of Escherischia coli O157:H7 and spoilage yeasts in germicidal UV-C-irradiated and heat-treated clear apple juice. J. Food Control 2012, 25, 425-432. [CrossRef]

58. Gayan, E.; Monfort, S.; Alavarez, I.; Condon, S. UV-C inactivation of Escherischia coli at different temperatures. Innov. Food Sci. Emerg. Technol. 2011, 12, 531-541. [CrossRef]

59. Gomez, P.L.; Garcia-Loredo, A.; Salvatori, D.M.; Guerrero, S.; Alzamora, S.M. Viscoelasticity, texture and ultrastructure of cut apple as affected by sequential anti-browning and ultraviolet-C light treatments. J. Food Eng. 2011, 107, 214-225. [CrossRef]

60. Lu, G.; Li, C.; Liu, P.; Cui, H.; Xia, Y.; Wang, J. Inactivation of microorganisms in apple juice using an ultraviolet silica-fiber optical device. J. Photochem. Photobiol. 2010, 100, 167-172. [CrossRef] [PubMed]

61. Ukuku, D.; Geveke, D.J. A combined treatment of UV-C-light and radio frequency electric field for the inactivation of Escherichia coli K-12 in apple juice. Int. J. Food Microbiol. 2010, 138, 50-55. [CrossRef] [PubMed]

62. Lopez-Malo, A.; Palou, A.; Jimenez-Fernandes, M.; Alzamora, S.M.; Guerero, S. Multifactorial fungal inactivation combining thermosonication and antimicrobials. J. Food Eng. 2005, 67, 87-93. [CrossRef]

63. Ngadi, M.; Smith, J.P.; Cayouette, B. Kinetics of ultraviolet light inactivation of Escherischia coli O157:H7 in liquid foods. J. Sci. Food Agric. 2003, 83, 1551-1555. [CrossRef]

64. Palgan, I.; Caminiti, I.M.; Munoz, A.; Noci, F.; Whyte, P.; Morgan, D.J.; Cronin, D.A.; Lyng, J.G. Combined effect of selected non-thermal technologies on Escherichia coli and Pichia fermentans inactivation in an apple and cranberry juice blend and on product. Int. J. Food Microbiol. 2011, 151, 1-6. [CrossRef] [PubMed]

65. Fredericks, I.N.; du Toit, M.; Krugel, M. Efficacy of ultraviolet radiation as an alternative technology to inactivate microorganisms in grape jucies and wines. Int. J. Food Microbiol. 2011, 28, 510-517. [CrossRef] [PubMed]

66. Geveke, D.J.; Torres, D. Pasteurization of grapefruit juice using a centrifugal ultraviolet light irradiator. J. Food Eng. 2012, 111, 241-246. [CrossRef]

67. Oteiza, J.M.; Giannuzzi, L.; Zaritzky, N. Ultraviolet treatment of orange juice to inactivate E. coli O157:H7 as affected by native microflora. Food Bioprocess Technol. 2010, 3, 603-614. [CrossRef]

68. Ochoa-Velasco, C.E.; Guerrero-Beltrán, J.Á. Ultraviolet-C light effect on pitaya (Stenocereus griseus) juice. J. Food Res. 2013, 1, 60-70. [CrossRef]

69. Rosenfeldt, E.J.; Linden, K.G.; Canonica, S.; van Gunten, U. Comparison of the efficiency of OH radical formation during ozonation and the advanced oxidation processes $\mathrm{O}_{3} / \mathrm{H}_{2} \mathrm{O}_{2}$ and $\mathrm{UV}-\mathrm{C} / \mathrm{H}_{2} \mathrm{O}_{2}$. Water Res. 2006, 40, 3695-3704. [CrossRef] [PubMed] 
70. Yaun, B.R.; Sumner, S.S.; Eifert, J.D.; March, J.E. Inhibition of pathogens on fresh produce by ultraviolet energy. Int. J. Food Microbiol. 2004, 90, 1-8. [CrossRef]

71. Jagger, J. Introduction to Research in UV-C Photobiology; Prentice Hall, Inc: Englewood Cliffs, NJ, USA, 1967.

72. Sommer, R.; Pribil, W.; Appelt, S.; Gehringer, P.; Eschweiler, H.; Leth, H.; Cabaj, A.; Haider, T. Inactivation of bacteriophages in water by means of non-ionizing (UV-C-253.7nm) and ionizing (gamma) radiation: A comparative approach. Water Res. 2001, 35, 3109-3116. [CrossRef]

73. Koutchma, T.; Parisi, B.; Unluturk, S. Evaluation of UV-C dose in flow-through reactors for fresh apple juice and cider. Chem. Eng. Commun. 2006, 193, 715-728. [CrossRef]

74. Choudhary, R.; Bandla, S.; Watson, D.G.; Haddock, J.; Abughazaleh, A.; Bhattacharya, B. Performance of coiled tube ultraviolet reactors to inactivate Escherichia coli W1485 and Bacillus cereus endospores in raw cow milk and commercially processed skimmed cow milk. J. Food Eng. 2011, 101, 14-20. [CrossRef]

75. US Food and Drug Administration (USFDA). Hazard Analysis and Critical Control Point (HACCP); Procedures for the Safe and Sanitary Processing and Importing of Juice; Final Rule (21 CFR Part 120). USFDA: Silver Spring, MD, USA, 2001; Volume 66, pp. 6137-6202.

76. World Health Organization (WHO). IARC Classification of the Carcinogecity; World Health Organisation: Geneva, Switzerland, 1995.

77. Wegener, J.W.; Lopez-Sanchez, P. Furan levels in fruit and vegetables juices, nutrition drinks and bakery products. Ana. Chim. Acta 2010, 672, 55-60. [CrossRef] [PubMed]

78. Bule, M.V.; Desai, K.M.; Parisi, B.; Parulekar, S.J.; Slade, P.; Singhai, R.S. Furan formation during UV-C-treatment of fruit juices. Food Chem. 2010, 122, 937-942. [CrossRef]

79. Locas, C.P.; Yaylayan, V.A. Origin and mechanistic pathways of formation of the parent 746 furan-A food toxicant. J. Agric. Food Chem. 2004, 52, 6830-6836. [CrossRef] [PubMed]

80. Fan, X.T. Formation of furan from carbohydrates and ascorbic acid following exposure to 711 ionizing radiation and thermal processing. J. Agric. Food Chem. 2005, 53, 7826-7831. [CrossRef] [PubMed]

81. Belitz, H.-D.; Grosch, W. Food Chemistry; Springer-Verlag: New York, NY, USA, 2004; pp. 231, $232,506$.

82. Food and Drug Administration (FDA). Guidance for Industry: Juice HACCP Hazards and Controls Guidance 1st ed. Available online: http://www.fda.gov/Food/GuidanceComplianceRegulatoryInformation/ GuidanceDocuments/Juice/ucm072557.htm (accessed on 25 November 2010).

83. Zhao, D. Efficient reduction of pathogenic and spoilage microorganisms from apple cider by combining microfiltration with UV treatment. J. Food Prot. 2015, 78, 716-722. [CrossRef] [PubMed]

84. Shahbaz, H.M.; Yoo, S.; Seo, B.; Ghafoor, K.; Kim, J.U.; Lee, D.U.; Park, J. Combination of TiO $\mathrm{T}_{2}-\mathrm{UV}$ photocatalysis and high hydrostatic pressure to inactivate bacterial pathogens and yeast in commercial apple juice. Food Bioprocess Technol. 2016, 9, 182-190. [CrossRef]

85. Sew, C.C.; Ghazali, H.M.; Martin-Belloso, O.; Mohd Adzahan, N. Effects of combining ultraviolet and mild heat treatments on enzymatic activities and total phenolic contents in pineapple juice. Innov. Food Sci. Emerg. Technol. 2014, 26, 511-516. [CrossRef]

86. Gouma, M.; Gayán, E.; Rasoa, J.; Condón, S.; Álvarez, I. Inactivation of spoilage yeasts in apple juice by UV-C light and in combination with mild heat. Innov. Food Sci. Emerg. Technol. 2015, 32, 146-155. [CrossRef]

87. Gayán, E.; Mañas, P.; Álvarez, I.; Condón, S. Mechanism of the synergistic inactivation of Escherichia coli by UV-C-C light at mild temperatures. Appl. Environ. Microbiol. 2013, 79, 4465-4473. [CrossRef] [PubMed]

88. Flores-Cervantes, D.X.; palou, E.; Lopez-Malo, A. Efficacy of individual and combined UV-CC light and food microbial treatments to inactivate Asperigillus falvus and A. niger spores in peace nectar. Innov. Food Sci. Emerg. Technol. 2013, 20, 244-252. [CrossRef]

89. Gachovska, T.K.; Kumar, S.; Thippareddi, H.; Subbiah, J.; Williams, F. Ultraviolet and pulsed electric field treatments have additive effect on inactivation of E. coli in apple juice. J. Food Sci. 2008, 73, 412-417. [CrossRef] [PubMed]

90. Ferrario, M.; Alzamora, S.M.; Guerrero, S. Study of the inactivation of spoilage microorganisms in apple juice by pulsed light and ultrasound. Food Microbiol. 2015, 46, 635-642. [CrossRef] [PubMed]

91. Caminiti, A.M.; Noci, F.; Munoz, A.; Whyte, P.; Morgan, D.J.; Cronin, D.A.; Lyng, J.G. Impact of selected combinations of non-thermal processing technologies on the quality of an apple and cranberry juice blend. Food Chem. 2011, 124, 1387-1392. [CrossRef] 
92. Walking-Ribeiro, M.; Noci, F.; Cronin, D.A.; Riener, J.; Lyng, J.G.; Morgan, D.J. Reduction of Staphylococcus aureus and quality changes in apple juice processed by ultraviolet irradiation, pre-heating and pulsed electric fields. J. Food Eng. 2008, 89, 267-273. [CrossRef]

93. Tan, S.L. Effect of Combining Mild Heat with Ultraviolet Treatment on Quality of Green Guava Juice. Bachelor's Thesis, Universiti Putra Malaysia, Serdang, Selangor, Malaysia, 2012.

94. Gayán, E.; Serrano, M.J.; Monfort, S.; Álvarez, I.; Condón, S. Combining ultraviolet light and mild temperatures for the inactivation of Escherichia coli in orange juice. J. Food Eng. 2012, 113, 598-605. [CrossRef]

95. Char, C.D.; Mitilinaki, E.; Guerrero, S.R.; Alzamora, S.M. Use of high-intensity ultrasound and UV-C light to inactivate some microorganisms in fruit juices. Food Bioprocess Technol. 2010, 3, 797-803. [CrossRef]

96. Nur Zahirah, M.S. Safety and Quality of Watermelon Juice Treated by Combining Ultraviolet Irradiation with Citric Acid. Bachelor's Thesis, Universiti Putra Malaysia, Serdang, Selangor, Malaysia, 2009.

97. Tan, H.Y.; Ganesh, T.; Noranizan, M.A. Market Potential Analysis and Possible Marketing Strategy for Ultraviolet-Irradiated Single Strength Pineapple Juice in the Klang Valley. In Marketing: A Compendium; Cheng, K.T.G., Amer, H.J., Ganesh, T., Eds.; Universiti Putra Malaysia Press: Selangor, Malaysia, 2014; pp. 82-105.

98. Lau, P.L.; Mohd Adzahan, N.; Hashim, N.; Shamsudin, R.; Sew, C.C.; Sobhi, B. Pineapple juice production using ultraviolet pasteurisation: Potential cost implications. J. Agribus. Mark. 2011, 4, 38-50.

99. Worobo, R.W. Efficacy of the CiderSure 3500 ultraviolet light unit in apple cider. In Presented at the FDA Apple Cider Food Safety Control Workshop, Ithaca, NY, USA, 24 April 1998.

100. Majchrowicz, A. Innovative technologies could improve food safety. Food Saf. 1999, 22, 16-20.

101. Kozempel, M.; McAloon, A.; Yew, W. The cost of pasteurizing apple cider. J. Food Technol. 1998, 52, 50-52.

102. Higgins, K.T. Fresh Today, Safe Next week. Food Engineering Magazine. Available online: http://www. foodengineeringmag.com/articles/84458-fresh-today-safe-next-week (accessed on 12 March 2012).

(C) 2016 by the authors; licensee MDPI, Basel, Switzerland. This article is an open access article distributed under the terms and conditions of the Creative Commons Attribution (CC-BY) license (http://creativecommons.org/licenses/by/4.0/). 